\title{
Spring thaw ionic pulses boost nutrient availability and microbial growth in entombed Antarctic Dry Valley cryoconite holes
}

\author{
Jon Telling ${ }^{1 *}$, Alexandre M. Anesio ${ }^{1}$, Martyn Tranter ${ }^{1}$, Andrew G. Fountain ${ }^{2}$, Thomas Nylen ${ }^{2}$, \\ Jon Hawkings ${ }^{1}$, Virendra B. Singh ${ }^{3}$, Preeti Kaur ${ }^{4}$, Michaela Musilova ${ }^{1}$ and Jemma L. Wadham ${ }^{1}$ \\ 1 School of Geographical Sciences, University of Bristol, Bristol, UK \\ ${ }^{2}$ Department of Geology, Portland State University, Portland, OR, USA \\ ${ }^{3}$ School of Environmental Sciences, Jawaharlal Nehru University, New Delhi, India \\ ${ }^{4}$ School of Chemistry, University of Bristol, Bristol, UK
}

Edited by:

David Anthony Pearce, Northumbria University, UK

Reviewed by:

Anthony Yannarell, University of

Illinois at Urbana-Champaign, USA

Hongchen Jiang, Miami University,

USA

*Correspondence:

Jon Telling, School of Geographical

Sciences, University of Bristol,

University Road, Bristol BS8 1SS,

UK

e-mail: jon.telling@bristol.ac.uk
The seasonal melting of ice entombed cryoconite holes on McMurdo Dry Valley glaciers provides oases for life in the harsh environmental conditions of the polar desert where surface air temperatures only occasionally exceed $0^{\circ} \mathrm{C}$ during the Austral summer. Here we follow temporal changes in cryoconite hole biogeochemistry on Canada Glacier from fully frozen conditions through the initial stages of spring thaw toward fully melted holes. The cryoconite holes had a mean isolation age from the glacial drainage system of 3.4 years, with an increasing mass of aqueous nutrients (dissolved organic carbon, total nitrogen, total phosphorus) with longer isolation age. During the initial melt there was a mean nine times enrichment in dissolved chloride relative to mean concentrations of the initial frozen holes indicative of an ionic pulse, with similar mean nine times enrichments in nitrite, ammonium, and dissolved organic matter. Nitrate was enriched twelve times and dissolved organic nitrogen six times, suggesting net nitrification, while lower enrichments for dissolved organic phosphorus and phosphate were consistent with net microbial phosphorus uptake. Rates of bacterial production were significantly elevated during the ionic pulse, likely due to the increased nutrient availability. There was no concomitant increase in photosynthesis rates, with a net depletion of dissolved inorganic carbon suggesting inorganic carbon limitation. Potential nitrogen fixation was detected in fully melted holes where it could be an important source of nitrogen to support microbial growth, but not during the ionic pulse where nitrogen availability was higher. This study demonstrates that ionic pulses significantly alter the timing and magnitude of microbial activity within entombed cryoconite holes, and adds credence to hypotheses that ionic enrichments during freeze-thaw can elevate rates of microbial growth and activity in other icy habitats, such as ice veins and subglacial regelation zones.

Keywords: Antarctica, cryoconite, ionic pulse, nitrogen fixation, photosynthesis, bacterial production, McMurdo Dry Valleys, microbial ecology

\section{INTRODUCTION}

The McMurdo Dry Valleys (MDV) are polar deserts comprising the largest ice-free expanse in Antarctica, and represent one of the coldest and driest ecosystems on Earth (Fountain et al., 1999). Glacial melt is critically important for supplying liquid water not only to supraglacial ecosystems (cryoconite holes, cryolakes, and supraglacial streams) (Mueller et al., 2001; Tranter et al., 2004; Foreman et al., 2007) but also downstream ecosystems (ephemeral streams, sandy soils, and perennially ice covered lakes) in a short 6-10 week melt season during the Austral summer (Fountain et al., 1999).

Surface temperatures on the glaciers rarely exceed $0^{\circ} \mathrm{C}$ even in mid-summer so that the melting of the glacier surface typically initiates through the warming of relatively low albedo surface sediment (cryoconite) (Fountain et al., 2008). Cryoconite melts its way down into the glacier to form cylindrical water filled holes, with the surface water refreezing to form ice-lids that isolate the holes from the atmosphere. Eventually the cryoconite holes reach an equilibrium depth where the rate of melt deepening supported by incoming insolation through the ice-lids matches the rate of surface ablation (Mcintyre, 1984; Fountain et al., 2008). Individual holes can be isolated from the atmosphere for a year up to a decade or more (Tranter et al., 2004; Fountain et al., 2008), with a combination of physical processes (ice melt, mineral dissolution, and mineral precipitation reactions) and microbial activities forming unique water chemistries distinct from those of the surrounding ice (Tranter et al., 2004).

The presence of liquid water, nutrients, and sunlight within the cryoconite holes supports a wide range of prokaryotic and eukaryotic microbial life during the Austral summer (Wharton 
et al., 1981; Christner et al., 2003; Porazinska et al., 2004; Foreman et al., 2007), with significant rates of potential photosynthesis (Bagshaw et al., 2011), bacterial production and enzymatic activity (Foreman et al., 2007). The disparity in the organic matter content of MDV valley floor soils $\left(0.2 \pm 0.04 \mathrm{mg} \mathrm{C} \mathrm{g}^{-1}\right.$; Barrett et al., 2007) and glacier cryoconite (mean of $1.0 \mathrm{mg} \mathrm{C} \mathrm{g}^{-1}$ on Canada Glacier; Bagshaw et al., 2013) may be evidence that MDV cryoconite holes are net autotrophic ecosystems, although this has yet to be proven (Bagshaw et al., 2013). The ability of microbes on MDV glacier surfaces to fix nitrogen from the atmosphere has also yet to be tested, and could potentially provide an important source of bioavailable nitrogen for glacier microbial communities as previously documented on Arctic glaciers (Telling et al., 2011, 2012b). Ultimately, periodic warming events flush the cryoconite holes out, providing a potentially important supply of water and nutrients to downstream ephemeral streams and perennially ice covered lakes (Fountain et al., 2004; Foreman et al., 2007; Bagshaw et al., 2013).

One important aspect of cryoconite hole ecology that has not been explored to date is the impact of freeze-thaw events on microbial activity. Pulses of melt water during the first 2 weeks of the summer melt season (a significant fraction of the typical 6-10 week melt season) have highly elevated ionic concentrations up to two orders of magnitude greater than in fully thawed holes, with large diurnal variations (Fountain et al., 2008). These "ionic pulses" likely reflect the initial melting of brine ice formed during the freezing of cryoconite hole waters at the end of the previous melt season (Fountain et al., 2008). The impact of these ionic pulses on aqueous nutrient concentrations and microbial ecology within cryoconite holes has yet to be assessed. Analogous studies on early snow melt have documented the preferential elution of some ions over others (Davies et al., 1982; Cragin et al., 1996). During snow crystal growth, less soluble species such as $\mathrm{SO}_{4}^{2-}$, $\mathrm{Mg}^{2+}$, and $\mathrm{Ca}^{2+}$ are preferentially excluded from the ice crystals to form brine surface layers (Cragin et al., 1996). These brines are the first to melt in the spring, with $\mathrm{SO}_{4}^{2}, \mathrm{Mg}^{2+}$ and $\mathrm{Ca}^{2+}$ appearing sooner and in higher concentration in initial snow melt than more soluble ions such as $\mathrm{Cl}^{-}$(Cragin et al., 1996). It has been hypothesized that in MDV ice lidded cryoconite holes, early melt season nutrient rich "ionic pulses" may stimulate microbial growth after the winter freeze (Fountain et al., 2008).

In this paper, we aim to test the hypothesis that early melt season ionic pulse events have a significant impact on rates of microbial growth and activity within ice entombed cryoconite holes. We follow the temporal changes in cryoconite water chemistry and microbial activity (potential photosynthesis, heterotrophic bacterial production, and potential nitrogen fixation) in cryoconite holes through the start of the melt season on Canada Glacier in the MDV. This study will increase our understanding of cryoconite hole biogeochemistry, and help to define the role of cryoconite holes in the depauperate ecosystem of the MDV.

\section{MATERIALS AND METHODS SAMPLING AND FIELD ANALYSIS OF SAMPLES}

The sample site was located on the surface of Canada Glacier, located within the $34 \mathrm{~km}$ long Taylor Valley of the MDV, Antarctica. Eight ice-lidded cryoconite holes were sampled at four different time points on 25th November, 28th November, 30th November, and 5th December 2011, hereafter termed $T=0$, $T+3, T+5$, and $T+10$ (with the number referring to days since initial sampling). Eight ice cores with no underlying cryoconite were also sampled on 25th November 2011. All cryoconite holes were completely frozen at $T=0$, with increasing melt water at later time points. The same cryoconite holes were not sampled repeatedly; rather, eight different cryoconite holes were destructively sampled in the same local $10 \mathrm{~m}^{2}$ area of the glacier centered around the following coordinates: S $77^{\circ} 37.546^{\prime}$, E $162^{\circ} 57.620^{\prime}$. In all cases, samples were taken using a hand driven Kovacs ice corer. Prior to sampling, the width and length of the cryoconite holes (identifiable by the different crystal structure of the refrozen ice lids) were measured using a ruler $( \pm 0.5 \mathrm{~cm})$.

After coring, ice cores and fully frozen cryoconite holes were transferred to large polyethylene bags for and transported to the field laboratory. In the laboratory, cores were melted in the laboratory and samples treated as below for water samples. In cryoconite holes where liquid water was present, the ice lid was removed and the water depth, sediment depth, and hole depth were measured with a ruler $( \pm 0.5 \mathrm{~cm})$. Water was sampled using a $50 \mathrm{ml}$ plastic syringe and transferred into 1L HDPE bottles for later ion and nutrient analysis and $65 \mathrm{ml}$ glass BOD (Biological Oxygen Demand) bottles for dissolved inorganic carbon (DIC) and $\mathrm{pH}$ measurements later the same day. All HDPE bottles were rinsed three times with sample prior to filling. The BOD bottles were filled from the bottom using a length of Tygon ${ }^{\circledR}$ tubing attached to the syringe, and the bottle allowed to overflow $3 \times$ their volume prior to capping with no headspace. Cryoconite samples were collected with a stainless steel scoop into $50 \mathrm{ml}$ Falcon tubes. Ice samples were collected in polyethylene bags, melted in the laboratory and the water treated as below for water samples.

DIC was measured in a field laboratory by acidification of the water samples and measurement of the $\mathrm{CO}_{2}$ evolved using a portable PP systems EGM-4 infrared $\mathrm{CO}_{2}$ meter, with a coefficient of variation of $1 \%$ (Telling et al., 2010). $\mathrm{pH}$ was measured using a Thermo-Orion $\mathrm{pH}$ meter and probe. Water for later ion and nutrient analysis was filtered through Whatman Puradisc ${ }^{\circledR}$ $0.45 \mu \mathrm{m}$ inline filters into $30 \mathrm{ml}$ HDPE bottles after washing three times with sample, and immediately frozen at $-20^{\circ} \mathrm{C}$. Water for $\delta^{18} \mathrm{O}-\mathrm{H}_{2} \mathrm{O}$ analysis were filtered through Whatman Puradisc ${ }^{\circledR} 0.45 \mu \mathrm{m}$ inline filters into $30 \mathrm{ml}$ HDPE bottles, leaving no headspace.

\section{MELTED ICE AND CRYOCONITE WATER GEOCHEMICAL ANALYSES}

Dissolved anions $\left(\mathrm{Cl}^{-}, \mathrm{NO}_{3}^{-}, \mathrm{SO}_{4}^{2-}\right)$ and cations $\left(\mathrm{Na}^{+}, \mathrm{K}^{+}\right.$, $\left.\mathrm{Ca}^{2+}, \mathrm{Mg}^{2+}\right)$ were analyzed on a dual system Thermofisher Dionex 5000 capillary ion chromatograph with IonPac AS11$\mathrm{HC}(0.4 \times 250 \mathrm{~mm})$ and $\mathrm{CS} 16(0.5 \times 250 \mathrm{~mm})$ columns at $30^{\circ} \mathrm{C}$, using $32.2 \mathrm{mM} \mathrm{KOH}$ and $30 \mathrm{mM}$ methanesulfonic acid (MSA) as eluents for anions and cations, respectively. Detection limits for $\mathrm{Cl}^{-}, \mathrm{NO}_{3}^{-}$, and $\mathrm{SO}_{4}^{2-}$ were $0.5,0.6$, and $0.2 \mu$ moles $\mathrm{L}^{-1}$ respectively, with coefficients of variation of $0.8,2.4$, and $1.9 \%$ $(n=10)$. Detection limits for $\mathrm{Na}^{+}, \mathrm{K}^{+}, \mathrm{Ca}^{2+}, \mathrm{Mg}^{2+}$ were 2.7, $1.4,1.0$, and $0.1 \mu$ moles $\mathrm{L}^{-1}$ respectively, with coefficients of variation of $1.8,2.7,1.9$ and $1.9 \%(n=10)$. Dissolved organic 
carbon (DOC) was analyzed on a Shimadzu TOC-V CSN analyzer. The detection limit was $10.1 \mu$ moles $\mathrm{L}^{-1}$ with a coefficient of variation of $6.4 \%(n=6) . \mathrm{NO}_{2}^{-}$and $\mathrm{NH}_{4}^{+}$were analyzed on a Bran + Luebbe Autoanalyzer 3, with detection limits of 0.09 and $0.4 \mu$ moles $\mathrm{L}^{-1}$ respectively, and coefficients of variation of 1.5 and $9.2 \%$, respectively. $\mathrm{PO}_{4}^{3-}$, total dissolved phosphorus $\left(\mathrm{TP}_{(\mathrm{aq})}\right)$ and total dissolved nitrogen $\left(\mathrm{TN}_{(\mathrm{aq})}\right)$ were analyzed on a Lachat QuickChem 8500 Series 2 Flow Injector Analyzer using standard QuikChem ${ }^{\circledR}$ methods 31-115-01-1-I, 31-115-01-3-F and 31-107-04-3-A, respectively. Detection limits were 0.036, 1.4, and $1.0 \mu$ moles $\mathrm{L}^{-1}$ for $\mathrm{PO}_{4}^{3-}, \mathrm{TP}_{(\mathrm{aq})}$ and $\mathrm{TN}_{(\mathrm{aq})}$ respectively, with coefficients of variation of $0.5,3.4$, and $7.4 \%(n=6)$. Dissolved organic nitrogen $(\mathrm{DON})$ was defined as $\mathrm{TN}_{(\mathrm{aq})}-\left[\mathrm{NH}_{4}^{+}+\right.$ $\mathrm{NO}_{2}^{-}+\mathrm{NO}_{3}^{-}$. Dissolved organic phosphorus (DOP) was defined as $\mathrm{TP}_{(\mathrm{aq})}-\mathrm{PO}_{4}^{3-}$.

The $\delta^{18} \mathrm{O}-\mathrm{H}_{2} \mathrm{O}$ of samples (a proxy for the percentage of ice melt within the cryoconite holes; see below) was analyzed using a Picarro L1120-i cavity ringdown spectrometer, with a precision of $\pm 0.2 \%$. Inorganic carbon speciation in $T+10$ cryoconite holes (the only time point where $\mathrm{pH}$ was reliably measured) was modeled using the computer program PHREEQ-C using its standard database.

\section{CRYOCONITE GEOCHEMICAL ANALYSES}

Three cryoconite samples from each time point were analyzed for TOC, IC, and TN. All eight cryoconite samples from each time point were analyzed for solid phase nitrogen and phosphorus speciation. Dried cryoconite samples $\left(105^{\circ} \mathrm{C}\right.$, overnight) were analyzed for total organic carbon (TOC) and total nitrogen (TN) on a Eurovector EA3000 Elemental Analyzer. Detection limits for TOC and TN were $100 \mu \mathrm{g} \mathrm{C} \mathrm{g}^{-1}$ and $100 \mu \mathrm{g} \mathrm{N} \mathrm{g}^{-1}$ respectively, with coefficients of variation for duplicate analyses of 9.5 and $5.3 \%$. Exchangeable $\mathrm{NH}_{4}^{+}, \mathrm{NO}_{3}^{-}$, and $\mathrm{NO}_{2}^{-}$in wet cryoconite were extracted using a $2 \mathrm{M} \mathrm{KCl}$ method (Telling et al., 2011). Extracts were analyzed on a Bran and Luebbe Autoanalyzer 3. Results were converted to dry weights after weighing cryoconite before and after oven drying. The average coefficients of variation for duplicate $\mathrm{NH}_{4}^{+}$and $\mathrm{NO}_{3}^{-}$analyses were 35.7 and $37.8 \%$, respectively. Potentially bioavailable and residual phosphorus $\left(\mathrm{P}_{\text {residual }}\right)$ in dried cryoconite were analyzed using a three stage sequential digestion method using (1) $1 \mathrm{M} \mathrm{MgCl}_{2}$, (2) $0.1 \mathrm{M} \mathrm{NaOH}$ and (3) acid persulfate. Extracts were analyzed on a Shimadzu mini UV-vis spectrophotometer. The average coefficients of variation for duplicate cryoconite samples for the $\mathrm{MgCl}_{2}$, $\mathrm{NaOH}$, and persulfate digestion steps were $10.1,6.2$, and $10.3 \%$, respectively.

\section{CRYOCONITE MICROBIOLOGICAL ANALYSES}

Three cryoconite samples from each time point were analyzed for total cell counts, autofluorescent counts, and biomass estimates. All eight samples at each time point were assayed for potential photosynthesis, bacterial production, and potential nitrogen fixation. Total and autofluorescent cell counts were enumerated by epifluorescent microscopy (Stibal et al., 2012). After thawing, $20 \mathrm{mg}$ of the cryoconite were placed into a preweighed sterile Eppendorf tube and $1 \mathrm{~mL}$ of pre-sterilized deionized water, gluteraldehyde ( $2 \%$ final concentration) and sodium pyrophosphate $(0.001 \mathrm{M}$ final concentration) were added and vortexed for $1 \mathrm{~min}$. The mixture was then sonicated for $2 \mathrm{~min}$, shaken vigorously and $100 \mu \mathrm{l}$ of the supernatant diluted 1:10 with autoclaved Milli-Q water. Microbial cells were stained with $4^{\prime}$, 6-diamidino-2-phenylindole (DAPI, Sigma) $\left(10 \mu \mathrm{g} \mathrm{mL}^{-1}\right.$ final concentration) and samples filtered onto black $0.22 \mu \mathrm{m}$ polycarbonate filters (Millipore). Over 300 stained bacterial cells per slide were counted in duplicate using epifluorescence microscopy, and procedural blanks (sterilized deionized water) were subtracted from the sample counts. The same procedure was followed to enumerate photoautotrophic microbes using chlorophyll autofluorescence instead of staining the samples with DAPI (Stibal et al., 2012). Individual cell dimensions were digitally measured and biovolume calculated for each sample using an F-view II CCD (Olympus) and Cell ${ }^{\wedge} \mathrm{f}$ software (Olympus) (Bellas et al., 2013). Conversion factors reported by Bellas et al. (2013) were used to calculate the carbon content (fg C cell ${ }^{-1}$ ) from biovolume.

Due to time constraints, rates of microbiological activity were measured on cryoconite samples with the addition of cryoconite water from the same hole, rather than analyzing water and cryoconite samples separately. A drawback of this approach is that the incubations had different cryoconite:water volumes to in situ holes. Previous research has demonstrated that microbiological activity is focused in cryoconite (e.g., bacterial production rates are on average $95 \%$ higher in cryoconite rather than overlying water on Canada Glacier; Foreman et al., 2007), hence the microbial rates of this study likely dominantly reflect rates in the cryoconite debris. Potential photosynthesis in cryoconite was measured using a modified ${ }^{14} \mathrm{C}-\mathrm{NaHCO}_{3}$ method (Telling et al., 2010), within the Lake Hoare radioactive laboratory. Samples of sediment were placed in $8 \mathrm{ml}$ polyethylene tubes to give a similar sediment depth $(0.5 \mathrm{~cm})$ to the in situ cryoconite holes. Water from the respective cryoconite hole was then added to the vial to leave no headspace, then $2 \mu \mathrm{l}$ of a stock solution of a $37 \mathrm{MBq}$ ${ }^{14} \mathrm{C}-\mathrm{NaHCO}_{3}$ solution (Perkin Elmer) was added. For each sample triplicate light, triplicate dark (covered with aluminum foil), and triplicate killed ( $100 \mu 150 \%$ v/v glutaraldehyde added) vials were incubated for $1.5 \mathrm{~h}$ in an ice bath under a lamp. The average photosynthetically active radiation (PAR) at the surface of the ice bath measured using an Apogee PAR sensor and meter was $100 \mu$ moles $\mathrm{m}^{-2} \mathrm{~s}^{-1}$ with a spatial variation of $\pm 20 \mu$ moles $\mathrm{m}^{-2} \mathrm{~s}^{-1}$. It should be noted that the actual PAR levels below ice lids in the cryoconite holes were not measured hence these rates of photosynthesis should be viewed as potential only. Vials were incubated for $1.5 \mathrm{~h}$ then removed from the ice bath and filtered through $0.45 \mu \mathrm{m}$ cellulose nitrate filters. The $\mathrm{pH}$ of the filtrate was immediately raised to $>\mathrm{pH} 10$ by the addition of pellets of $\mathrm{NaOH}$ prior to disposal. The filters were fumigated with $50 \%$ glutaraldehyde and $37 \% \mathrm{v} / \mathrm{v} \mathrm{HCl}$ for $>1 \mathrm{~h}$, and the filters placed in scintillation vials. Vials were transported to the main laboratory (McMurdo), where $10 \mathrm{ml}$ of Cytoscint ES scintillation cocktail was added and DPM values measured using a Beckman LS6000 scintillation counter, calibrated using external quench standards. Rates of photosynthesis $\left(\mu \mathrm{g} \mathrm{C} \mathrm{g}^{-1} \mathrm{~h}^{-1}\right.$ ) were calculated following the procedures of Telling et al. (2010).

Bacterial production was measured using ${ }^{3} \mathrm{H}$ leucine uptake within the field laboratory (Anesio et al., 2010). Quadruplicate 
cryoconite samples were placed into sterile $1.8 \mathrm{ml}$ microcentrifuge tubes and ${ }^{3} \mathrm{H}$-leucine added to give a final concentration of $100 \mathrm{nM}$. One of the four tubes was killed using the addition of $100 \mu \mathrm{l}$ of $50 \%$ glutaraldehyde. Tubes were wrapped in aluminum foil, incubated in an ice bath for $1.5 \mathrm{~h}$, then activity terminated by the addition of $100 \mu l$ 50\% glutaraldehyde. Samples were then transported to the Crary Laboratory (McMurdo), where $90 \mu \mathrm{l}$ of $100 \%$ ice cold trichloroacetic acid was added to samples, and the tubes centrifuged at $16,000 \mathrm{~g}$ for $10 \mathrm{~min}$. The pellet was washed sequentially with $5 \%$ trichloracetic acid and $80 \%$ ethanol and samples dried and weighed. Finally, $1 \mathrm{ml}$ of Cytosint ES cocktail was added to samples, and DPM counted on a Beckman LS6000 scintillation counter calibrated using external quench standards. Bacterial production rates $\left(\mu \mathrm{g} \mathrm{Cg}^{-1} \mathrm{~h}^{-1}\right)$ were calculated following the methods of Anesio et al. (2010).

Potential nitrogen fixation was measured by a modified acetylene assay (Stewart et al., 1967; Telling et al., 2011). For each sample, triplicate $30 \mathrm{ml}$ vials containing $0.5 \mathrm{~cm}$ deep sediment had $1.5 \mathrm{ml}$ of acetylene added and incubated for $24 \mathrm{~h}$ in an ice bath under a $100 \pm 20 \mu$ moles $\mathrm{cm}^{-2} \mathrm{~s}^{-1}$ PAR fluorescent lamp. A further $30 \mathrm{ml}$ bottle for each sample was incubated as above but without the addition of acetylene to check for in situ production of ethylene. A total of 13 bottles were run during the incubations with no sediment but with acetylene added to correct for the starting concentration of ethylene. After sampling, the cryoconite in each bottle was dried and weighed. Positive potential nitrogen fixation assays were defined as those bottles with an ethylene content more than $3 \times \mathrm{SD}$ of the acetylene only blanks after the mean blank value had been subtracted. Ethylene results in ppm were converted to $\mu$ moles after accounting for ethylene dissolution in water (Breitbarth et al., 2004). Rates were normalized to units of $\mu \mathrm{g} \mathrm{N} \mathrm{g}^{-1}$ assuming a 3:1 ratio between ethylene generated and dinitrogen fixed (Stewart et al., 1967) and a linear production of ethylene over time (Telling et al., 2011).

\section{NUMERICAL ANALYSIS}

\section{Enrichment factors}

Enrichment factors, where for example ion and nutrient concentrations in cryoconite holes are normalized to mean concentrations in the surrounding ice, can greatly facilitate the identification of biogeochemical sources and sinks (Tranter et al., 2004). In this study we define an enrichment factor $\left(X F_{0-i c e}\right)$ between fully frozen cryoconite holes and surrounding ice cores as follows:

$$
X F_{T 0-i c e}=\frac{C_{T=0}}{\text { mean } C_{i c e}}
$$

where $C_{T=0}$ is the concentration in the fully frozen cryoconite hole $(T=0)$, and mean $C_{i c e}$ is the mean concentration in the ice cores.

Similarly, we define enrichment factors between partially melted cryoconite holes $(T+3, T+5, T+10)$ and fully frozen cryoconite holes $(T=0)$ to facilitate the identification of biogeochemical processes occurring during early melt freeze-thaw effects as follows (using the example for $T+n$ ):

$$
X F_{T n-T 0}=\frac{C_{T+n}}{\text { mean } C_{T=0}}
$$

where $C_{T+n}$ is the concentration, nutrient ratio or microbial rate in $T+3, T+5$, or $T+10$ cryoconite holes and mean $C_{T=0}$ frozen is the mean concentration or microbial rate in the fully frozen cryoconite holes $(T=0)$.

\section{Correlations against $\delta^{18} \mathrm{O}-\mathrm{H}_{2} \mathrm{O}$, a proxy for the percentage ice melt}

The percentage ice melt in individual cryoconite holes at each time point is likely to vary substantially due to differential shading effects from variations in local topography and hole dimensions (Table 1). We therefore use the $\delta^{18} \mathrm{O}$ of the water as a more quantitative proxy than time for the percentage of ice melt within each individual hole, since the initial melt water should be enriched in the lighter ${ }^{16} \mathrm{O}-\mathrm{H}_{2} \mathrm{O} .{ }^{16} \mathrm{O}-\mathrm{H}_{2} \mathrm{O}$ preferentially partitions into the water phase relative to the heavier ${ }^{18} \mathrm{O}_{-} \mathrm{H}_{2} 0$ (Hoefs, 1980). We use Pearson correlation coefficients (SPSS statistical software package) to test the significance of relationships between $\delta^{18} \mathrm{O}-\mathrm{H}_{2} 0$ and aqueous ions and $\delta^{18} \mathrm{O}-\mathrm{H}_{2} 0$ and cryoconite microbial activity. We transformed the data by taking the logarithm of aqueous ion and cryoconite activity data to linearise the data prior to carrying out the Pearson correlation analyses.

\section{Isolation age}

The isolation age of the cryoconite waters from the surrounding supraglacial water system was estimated using chloride mass balance, following the approach of Fountain et al. (2004). Chloride is a conservative ion that will accumulate within ice lidded cryoconite holes as the holes melt into the glacier to keep pace with annual sublimation. We calculate the isolation ages of the frozen cryoconite holes $(T=0)$ using Equation 3 from Fountain et al. (2004), assuming: (a) an annual rate of sublimation of $8 \mathrm{~cm} \mathrm{a}^{-1}$, (b) that the initial cryoconite water and additional annual ice melt have chloride concentrations equivalent to the mean chloride concentration of sediment free ice and, (c) that the ice lids

Table 1 | Physical data for cryoconite holes, Canada Glacier.

\begin{tabular}{llccccc}
\hline Time & $\begin{array}{l}\text { Date } \\
(\mathbf{m} / \mathbf{d} / \mathbf{y})\end{array}$ & $\begin{array}{c}\text { Hole } \\
\text { diameter } \mathbf{( c m})\end{array}$ & $\begin{array}{c}\text { Hole } \\
\text { depth } \mathbf{( c m})\end{array}$ & $\begin{array}{c}\text { Sediment } \\
\text { depth }(\mathbf{c m})\end{array}$ & $\begin{array}{c}\text { Water } \\
\text { depth }(\mathbf{c m})\end{array}$ & $\begin{array}{c}\text { Ice lid } \\
\text { depth }(\mathbf{c m})\end{array}$ \\
\hline$T=0$ & 11.25 .11 & $25.8 \pm 5.6$ & $16.2 \pm 5.5$ & $1.5 \pm 0.5$ & $0.0 \pm 0.0$ & $16.2 \pm 5.5$ \\
$\mathbf{a g e}(\mathbf{y e a r s})$
\end{tabular}

Uncertainty is $1 \sigma(n=8)$. 
contain no chloride (Fountain et al., 2004). In reality, there is likely to be some chloride contained within the ice lid, although at a smaller concentration than in the cryoconite water (Bagshaw et al., 2007). We make an estimate of the possible errors in our estimates of isolation age by calculating the potential mass of chloride in each of the cryoconite hole ice lids by assuming a mean ratio of chloride in ice lid:water of 1:3.6 (Bagshaw et al., 2007). For $T+10$ cryoconite holes, where the volume of water exceeds that of the ice lids, the mean potential error in isolation ages is $28 \%$. At $T+3$ and $T+5$, the volume of overlying ice lid greatly exceeded that of the water volume in the hole, which together with the uncertainties in the depth measurements of the low volumes of water precludes an accurate assessment of total chloride mass in each cryoconite hole and hence an accurate estimate of isolation age. The significance of relationships between isolation age and the mass of dissolved nutrients in each hole is assessed using linear regression analysis (SPSS statistical software package) after normalizing ion and nutrient data to the surface area of the holes in order to negate the impact of concentration and dilution of nutrients by freeze-thaw.

\section{Aqueous nutrient mass balance within cryoconite holes}

Comparison of the rate of influx of nutrients from ice ablation into cryoconite holes with rates of microbial growth can give insight into potential microbial nutrient limitations (Hodson et al., 2013). Here we estimate fluxes of dissolved nutrients from ice ablation into the $T=0$ and $T+10$ cryoconite holes with the measured nutrient demands of bacterial production and photosynthesis:

$$
\begin{aligned}
& F=C_{i c e} \times Z \\
& D=\frac{\text { activity rate } \times M \times R}{A}
\end{aligned}
$$

where $\mathrm{F}$ is the nutrient flux [DOC, DIC, $\mathrm{TN}_{(\mathrm{aq})}$ or $\mathrm{TP}_{(\mathrm{aq})}$ ] from ice ablation into the hole ( $\mu$ moles $\mathrm{m}^{-2} \mathrm{~h}^{-1}$ ), based on the concentration of nutrients in the ice, $C_{i c e}$, and the ablation rate, $Z$ (calculated assuming a constant ablation rate of $8 \mathrm{~cm}$ over 10 weeks, equivalent to $0.048 \mathrm{~mm} \mathrm{~h}^{-1}$ ), $D$ is the estimated nutrient demand $(\mathrm{C}, \mathrm{N}$, or $\mathrm{P})$ from bacterial production or photosynthesis within the cryoconite hole ( $\mu$ moles $\left.\mathrm{m}^{-2} \mathrm{~h}^{-1}\right)$, activity rate is the measured rate of bacterial production or photosynthesis in the cryconite $\left(\mu\right.$ moles $\mathrm{g}^{-1} \mathrm{~h}^{-1}$ ), $M$ is the dry mass of cryoconite within the hole (calculated as the product of surface area, mean cryoconite depth, and mean cryoconite density $\left(1.3 \mathrm{~g} \mathrm{ml}^{-1}\right.$; Section Physical Dimensions of Cryoconite Holes), the Redfield coefficient, $R$, is 1 for $C, 1 / 16$ for $\mathrm{N}$, and $1 / 106$ for $\mathrm{P}$, and $A$ is the plan view area of the cryoconite hole $\left(\mathrm{m}^{2}\right)$.

The potential importance of nitrogen fixation for sustaining microbial growth within the fully melted cryoconite holes is estimated as follows. First, we convert the potential nitrogen fixation rates in units of $\mu$ moles $\mathrm{N} \mathrm{g}^{-1}$ (Table 6) to potential carbon fixed ( $\mu$ moles $\mathrm{C}^{-1}$ ) assuming a $\mathrm{C}: \mathrm{N}$ molar ratio of 6.6:1 (Redfield et al., 1963). We then compare these rates to the measured rates of bacterial production and photosynthesis.

\section{RESULTS}

\section{PHYSICAL DIMENSIONS OF CRYOCONITE HOLES}

Mean water depths in the holes increased with time to a maximum of $12.1 \pm 4.9 \mathrm{~cm}$ at $T+10$ (Table 1). Mean cryoconite debris thicknesses ranged from 0.6 to $2.5 \mathrm{~cm}$, with no consistent trend with time (Table 1 ). The mean cryoconite density (based on dry weights of known volumes of debris) was $1.3 \pm 0.6 \mathrm{~g}$ dry cryoconite $\mathrm{ml}^{-1}(n=64)$.

\section{ICE AND AQUEOUS GEOCHEMISTRY}

Ice core and aqueous geochemistry of cryoconite holes is summarized in Table 2. Mean chloride concentrations in fully frozen cryoconite holes were enriched $3.2 \times$ over ice cores (Table 3, Figure 1). Mean enrichment factors for $\mathrm{Ca}^{2+}(20.7 \times), \mathrm{Mg}^{2+}$ $(8.2 \times)$, and $\mathrm{SO}_{4}^{2-}(9.1 \times)$ were higher than those of $\mathrm{Cl}^{-}$(Table 3, Figure 1). Mean enrichment factors for DIC $(3.1 \times)$ were similar to those of $\mathrm{Cl}^{-}$, DOC $(2.4 \times), \mathrm{Na}^{+}(2.0 \times)$, and $\mathrm{K}^{+}(2.6 \times)$. All dissolved nitrogen and phosphorus species $\left(\mathrm{NO}_{3}^{-}, \mathrm{NH}_{4}^{+}, \mathrm{NO}_{2}^{-}\right.$, DON, DOP, $\mathrm{PO}_{4}^{3-}$ ) were depleted relative to $\mathrm{Cl}^{-}$with enrichment factors $<2 \times$ (Table 3, Figure 1).

The isotopic values of $\delta^{18} \mathrm{O}-\mathrm{H}_{2} \mathrm{O}$ during the first melt $(T+3)$ were lower relative to frozen cryoconite holes at $T=0$ (Table 2). The mean $\mathrm{Cl}^{-}$concentration in early melt waters $(T+3)$ was enriched $9.3 \times$ over fully frozen cryoconite holes $(T=0)$, alongside $>9 \times$ increases in mean $\mathrm{NO}_{3}^{-}, \mathrm{NO}_{2}^{-}, \mathrm{Mg}^{2+}$, and $\mathrm{DOC}$ concentrations (Table 3, Figure 1). Enrichment factors for $\mathrm{SO}_{4}^{2-}$, $\mathrm{Na}^{+}, \mathrm{K}^{+}, \mathrm{Ca}^{2+}, \mathrm{DON}$, and DOP were all lower than that of $\mathrm{Cl}^{-}$, ranging from $6.1 \times$ to $2.4 \times$. The mean enrichment factor for $\mathrm{PO}_{4}^{3-}$ was close to unity $(1.1 \times)$, while the mean DIC was depleted at $T+3(0.5 \times)$ relative to $T=0$. A plot of DIC against DOC indicates two distinct groups of samples: those with a relatively constant DOC level but varying DIC concentration (all of $T=0$, all $T+10$, all but one of $T+5$; Pearson correlation, $R=0.395$, $p=0.062, n=23$ ) and those with a relatively constant DIC concentration and higher and varying DOC concentrations $(T+3$, one of $T+5$; Figure 2 ).

There were significant positive Pearson correlations $(p<0.01)$ between $\delta^{18} \mathrm{O}-\mathrm{H}_{2} \mathrm{O}$ and $\log$ enrichment factors for $\mathrm{Cl}^{-}, \mathrm{SO}_{4}^{2-}$, $\mathrm{NO}_{3}^{-}, \mathrm{NO}_{2}^{-}, \mathrm{TN}, \mathrm{Mg}^{2+}, \mathrm{Ca}^{2+}, \mathrm{DON}, \mathrm{DOP}$, and DOC and a less strong $(p<0.05)$ correlation between $\delta^{18} \mathrm{O}-\mathrm{H}_{2} 0$ and the $\log$ enrichment factor for $\mathrm{K}^{+}$(Figure 1). There were no significant Pearson correlations between $\delta^{18} \mathrm{O}-\mathrm{H}_{2} \mathrm{O}$ and log enrichment factor for $\mathrm{PO}_{4}^{3-}(R=-0.1, p=0.601)$ or between $\delta^{18} \mathrm{O}-\mathrm{H}_{2} 0$ and $\log$ enrichment factor for DIC $(R=0.04, p=0.842)$ (Figure 1).

$\mathrm{pH}$ was only measured in cryoconite holes at $T+10$, with a mean of $8.9 \pm 1.0$. The dominant DIC species at $T=$ was $\mathrm{HCO}_{3}^{-}$, comprising $85-98 \%$ of inorganic carbon. $\mathrm{CO}_{2(\mathrm{aq})}$ concentrations varied from 0.05 to $12.9 \mu$ moles $\mathrm{L}^{-1}$, with a mean of $2.6 \pm 4.7 \mu$ moles $\mathrm{L}^{-1}$.

The mean molar dissolved DOC: $\mathrm{TN}_{(\mathrm{aq})}$ in ice cores was $4.5 \pm 1.3$ (Table 4), lower than the Redfield ratio of 6.6. The mean DOC:TN( $\mathrm{Tq}_{(\mathrm{aq})}$ of cryoconite holes were elevated relative to the surrounding ice, bracketing the Redfield ratio at 5.9-9.6 (Table 4). There was a significant Pearson correlation $(p<0.01)$ between $\delta^{18} \mathrm{O}-\mathrm{H}_{2} \mathrm{O}$ and DOC:TP $(\mathrm{aq})$ but not between $\delta^{18} \mathrm{O}-\mathrm{H}_{2} \mathrm{O}$ vs. DOC:TN or $\delta^{18} \mathrm{O}-\mathrm{H}_{2} 0$ vs. TN:TP $(\mathrm{aq})(R=-0.14, p=0.46$, and $R=-0.23, p=0.197$, respectively) (Figure 3). 
Table 2 | Aqueous geochemistry of Canada Glacier ice cores and cryoconite holes.

\begin{tabular}{|c|c|c|c|c|c|c|c|c|c|c|c|c|c|c|c|}
\hline & \multirow{2}{*}{$\begin{array}{l}\% 0 \\
\delta^{18} \mathrm{O}-\mathrm{H}_{2} \mathrm{O}\end{array}$} & \multicolumn{14}{|c|}{$\mu$ moles $L^{-1}$} \\
\hline & & $\mathrm{Cl}^{-}$ & DIC & $\mathrm{Na}^{+}$ & $\mathbf{K}^{+}$ & $\mathrm{Ca}^{2+}$ & $\mathbf{M g}^{2+}$ & $\mathrm{SO}_{4}^{2-}$ & $\mathrm{NO}_{3}^{-}$ & $\mathrm{NH}_{4}^{+}$ & $\mathrm{NO}_{2}^{-}$ & DON & DOP & $\mathrm{PO}_{4}^{3-}$ & DOC \\
\hline Ice & $\begin{array}{l}-33.3 \\
\pm 2.7\end{array}$ & $\begin{array}{l}9.3 \\
\pm 1.6\end{array}$ & $\begin{array}{l}79 \\
\pm 18\end{array}$ & $\begin{array}{l}12.4 \\
\pm 2.0\end{array}$ & $\begin{array}{l}2.3 \\
\pm 1.2\end{array}$ & $\begin{array}{l}4.0 \\
\pm 1.6\end{array}$ & $\begin{array}{l}1.0 \\
\pm 0.3\end{array}$ & $\begin{array}{l}1.0 \\
\pm 0.5\end{array}$ & $\begin{array}{l}1.3 \\
\pm 0.7\end{array}$ & $\begin{array}{l}0.04 \\
\pm 0.13\end{array}$ & $\begin{array}{l}0.17 \\
\pm 0.18\end{array}$ & $\begin{array}{l}2.1 \\
\pm 1.0\end{array}$ & $\begin{array}{l}0.03 \\
\pm 0.01\end{array}$ & $\begin{array}{l}0.06 \\
\pm 0.04\end{array}$ & $\begin{array}{l}12.3 \\
\pm 12.2\end{array}$ \\
\hline$T=0$ & $\begin{array}{l}-33.4 \\
\pm 1.5\end{array}$ & $\begin{array}{l}26.7 \\
\pm 19.2\end{array}$ & $\begin{array}{l}242 \\
\pm 159\end{array}$ & $\begin{array}{l}24.4 \\
\pm 13.7\end{array}$ & $\begin{array}{l}5.9 \\
\pm 3.7\end{array}$ & $\begin{array}{l}82.7 \\
\pm 98\end{array}$ & $\begin{array}{l}5.9 \\
\pm 3.7\end{array}$ & $\begin{array}{l}6.0 \\
\pm 7.8\end{array}$ & $\begin{array}{l}1.6 \\
\pm 1.5\end{array}$ & $\begin{array}{l}0.0 \\
\pm 0.0\end{array}$ & $\begin{array}{l}0.05 \\
\pm 0.08\end{array}$ & $\begin{array}{l}2.7 \\
\pm 1.5\end{array}$ & $\begin{array}{l}0.06 \\
\pm 0.06\end{array}$ & $\begin{array}{l}0.07 \\
\pm 0.07\end{array}$ & $\begin{array}{l}29.3 \\
\pm 15.9\end{array}$ \\
\hline$T+3$ & $\begin{array}{l}-39.0 \\
\pm 1.4\end{array}$ & $\begin{array}{l}275 \\
\pm 124\end{array}$ & $\begin{array}{l}112 \\
\pm 1.4\end{array}$ & $\begin{array}{l}92.5 \\
\pm 39.6\end{array}$ & $\begin{array}{l}14.3 \\
\pm 6.6\end{array}$ & $\begin{array}{l}241 \\
\pm 104\end{array}$ & $\begin{array}{l}59.6 \\
\pm 28.6\end{array}$ & $\begin{array}{l}36.4 \\
\pm 14.7\end{array}$ & $\begin{array}{l}19.5 \\
\pm 20.8\end{array}$ & $\begin{array}{l}1.8 \\
\pm 1.5\end{array}$ & $\begin{array}{l}0.49 \\
\pm 0.47\end{array}$ & $\begin{array}{l}14.9 \\
\pm 5.3\end{array}$ & $\begin{array}{l}0.25 \\
\pm 0.09\end{array}$ & $\begin{array}{l}0.09 \\
\pm 0.02\end{array}$ & $\begin{array}{l}280 \\
\pm 101\end{array}$ \\
\hline$T+5$ & $\begin{array}{l}-35.9 \\
\pm 1.6\end{array}$ & $\begin{array}{l}108 \\
\pm 64.6\end{array}$ & $\begin{array}{l}190 \\
\pm 104\end{array}$ & $\begin{array}{l}70.5 \\
\pm 41.2\end{array}$ & $\begin{array}{l}12.6 \\
\pm 6.7\end{array}$ & $\begin{array}{l}133 \\
\pm 41.7\end{array}$ & $\begin{array}{l}27.0 \\
\pm 14.7\end{array}$ & $\begin{array}{l}18.7 \\
\pm 7.8\end{array}$ & $\begin{array}{l}6.0 \\
\pm 4.0\end{array}$ & $\begin{array}{l}0.3 \\
\pm 0.6\end{array}$ & $\begin{array}{l}0.15 \\
\pm 0.17\end{array}$ & $\begin{array}{l}11.8 \\
\pm 12.2\end{array}$ & $\begin{array}{l}0.36 \\
\pm 0.47\end{array}$ & $\begin{array}{l}0.1 \\
\pm 0.05\end{array}$ & $\begin{array}{l}103 \\
\pm 113\end{array}$ \\
\hline$T+10$ & $\begin{array}{l}-34.2 \\
\pm 2.4\end{array}$ & $\begin{array}{l}36.3 \\
\pm 17.4\end{array}$ & $\begin{array}{l}145 \\
\pm 70.6\end{array}$ & $\begin{array}{l}32.6 \\
\pm 15.3\end{array}$ & $\begin{array}{l}8.0 \\
\pm 5.0\end{array}$ & $\begin{array}{l}81.4 \\
\pm 47.7\end{array}$ & $\begin{array}{l}8.2 \\
\pm 6.5\end{array}$ & $\begin{array}{l}9.1 \\
\pm 5.8\end{array}$ & $\begin{array}{l}2.4 \\
\pm 0.9\end{array}$ & $\begin{array}{l}0.0 \\
\pm 0.0\end{array}$ & $\begin{array}{l}0.0 \\
\pm 0.0\end{array}$ & $\begin{array}{l}3.5 \\
\pm 1.3\end{array}$ & $\begin{array}{l}0.05 \\
\pm 0.04\end{array}$ & $\begin{array}{l}0.12 \pm \\
0.05\end{array}$ & $\begin{array}{l}44.3 \pm \\
13.7\end{array}$ \\
\hline
\end{tabular}

Uncertainty is $1 \sigma(n=8)$.

Table 3 | Mean enrichment factors for (a) Frozen cryoconite hole ions $(T=0)$ relative to mean ice core ions ( $\left.X F_{T 0-i c e}\right)$ and, (b) Partially melted cryoconite hole aqueous ions $(T=3, T=5, T=10)$ relative to mean starting frozen cryoconite hole ions $\left(X F_{T n-T 0}\right)$.

\begin{tabular}{|c|c|c|c|c|c|c|c|c|c|c|c|c|c|c|c|}
\hline Mean & $\delta^{18} 0-\mathrm{H}_{2} \mathrm{O}$ & $\mathrm{Cl}^{-}$ & DIC & $\mathrm{Na}^{+}$ & $\mathbf{K}^{+}$ & $\mathrm{Ca}^{2+}$ & $\mathbf{M g}^{2+}$ & $\mathrm{SO}_{4}^{2-}$ & $\mathrm{NO}_{3}^{-}$ & $\mathrm{NH}_{4}^{+}$ & $\mathrm{NO}_{2}^{-}$ & DON & DOP & $\mathrm{PO}_{4}^{3-}$ & DOC \\
\hline$X F_{T 0-i c e}$ & 0.99 & 3.2 & 3.1 & 2.0 & 2.6 & 20.7 & 5.7 & 6.1 & 1.6 & 0.8 & 0.8 & 1.3 & 1.8 & 1.4 & 2.4 \\
\hline$X F_{T 3-T 0}$ & 1.18 & 9.3 & 0.5 & 3.8 & 2.4 & 2.9 & 10.2 & 6.1 & 12.2 & 9.7 & 9.7 & 5.6 & 4.4 & 1.1 & 9.6 \\
\hline$X F_{T 5-T 0}$ & 1.09 & 3.6 & 0.8 & 2.9 & 2.1 & 1.6 & 4.6 & 3.1 & 3.7 & 3.0 & 3.0 & 4.4 & 6.2 & 1.5 & 3.5 \\
\hline$X F_{T 10-T 0}$ & 0.91 & 1.2 & 0.6 & 1.3 & 1.5 & 1.0 & 1.4 & 1.5 & 1.5 & 0.0 & 0.0 & 1.3 & 0.9 & 1.9 & 1.5 \\
\hline
\end{tabular}

\section{CRYOCONITE CHEMISTRY AND MICROBIAL ACTIVITY Solid phase composition}

The mean organic and inorganic carbon concentrations of cryoconite were $0.9 \pm 0.4$ and $0.5 \pm 0.3 \mathrm{mg} \mathrm{C} \mathrm{g}^{-1}$, respectively (Table 5). Only three of the 12 samples had detectable total nitrogen $\left(0.6 \mathrm{mg} \mathrm{N} \mathrm{g}^{-1}\right.$ at $T=0$, and $0.5 \mathrm{mg} \mathrm{N} \mathrm{g}^{-1}$ at $T+3$, $0.4 \mathrm{mg} \mathrm{N} \mathrm{g}^{-1}$ at $T+10$ ), the remainder contained $<0.1 \mathrm{mg} \mathrm{N} \mathrm{g}^{-1}$ (Table 5).

The mean concentrations of $\mathrm{N}_{\mathrm{KCl}}$ varied with time. The lowest mean concentrations of $\mathrm{NH}_{4}^{+} \mathrm{KCl}$ were at $T=0\left(85 \mathrm{ng} \mathrm{N} \mathrm{g}^{-1}\right)$, with a maximum at $T+3\left(962 \mathrm{ng} \mathrm{N} \mathrm{g}^{-1}\right)$ and reduced concentrations through $T+5$ to a mean of $316 \mathrm{ng} \mathrm{N} \mathrm{g}^{-1}$ at $T+10$ (Table 5). $\mathrm{NO}_{3}^{-} \mathrm{KCl}$ was below detection in all holes at $T=0$, with higher concentrations at $T+3$ and $T+5$ (means of 31 and $46 \mathrm{ng}$ $\mathrm{N} \mathrm{g}^{-1}$ ), which fell to a mean of $3.1 \mathrm{ng} \mathrm{N} \mathrm{g}^{-1}$ at $T+10$ (Table 5).

The concentrations of $\mathrm{P}$ in cryoconite showed little variation with time of sampling (Table 5). The majority of $\mathrm{P}$ was in the form of $\mathrm{P}_{\text {residual }}$ (mean of $1460 \mu \mathrm{g} \mathrm{P} \mathrm{g}^{-1}$ ), with low concentrations of $\mathrm{P}_{\mathrm{MgCl} 2}$ (mean of $0.5 \mu \mathrm{g} \mathrm{P} \mathrm{g}^{-1}$ ) and $\mathrm{P}_{\mathrm{NaOH}}$ (mean of $10.3 \mu \mathrm{g} \mathrm{P} \mathrm{g}^{-1}$ ) (Table 5).

\section{Microbial cell counts and activity measurements}

The mean total microbial cell counts in cryoconite was $7.03 \times 10^{8}$ $\pm 1.39 \times 10^{8}$ cells wet $\mathrm{g}^{-1}$ sediment (all time points, $n=12$; Table 6). The mean $\%$ of autotrophic cells (all time points, $n=$ 12) was $10.6 \pm 6.8 \%$ (Table 6). The mean total cell volume was $0.083 \pm 0.04 \mu \mathrm{m}^{3}$, while the mean autofluorescent cell volume was $3.9 \times$ larger at $0.32 \pm 0.42 \mu \mathrm{m}^{3}$ (Table 6). The mean DAPI cell biomass was $12.8 \pm 7.0 \mu \mathrm{g} \mathrm{C} \mathrm{g}^{-1}$ wet sediment, and mean autofluorescent cell biomass lower at $6.8 \pm 12.3 \mu \mathrm{g} \mathrm{C} \mathrm{g}^{-1}$ (Table 6). The mean autofluorescent cell biomass was higher at
$T+3\left(14.4 \mu \mathrm{g} \mathrm{C} \mathrm{g}^{-1}\right)$ relative to other time points (0.9-6.5 $\mu \mathrm{g} \mathrm{C}$ $\mathrm{g}^{-1}$ wet sediment) (Table 6 ).

Rates of bacterial production in individual cryoconite holes ranged from 0.3 to $6.8 \mathrm{ng} \mathrm{C}^{-1} \mathrm{~g}^{-1} \mathrm{~h}^{-1}$, with a mean of $2.4 \pm$ $1.6 \mathrm{ng} \mathrm{C}^{-1} \mathrm{~g}^{-1} \mathrm{~h}^{-1}(n=32$; Table 7$)$. Rates of potential photosynthesis in individual cryoconite holes ranged from 1.2 to $47.8 \mathrm{ng} \mathrm{C}^{-1} \mathrm{~g}^{-1} \mathrm{~h}^{-1}$, with a mean of $15.3 \pm 11.7 \mathrm{ng} \mathrm{C}^{-1} \mathrm{~g}^{-1}$ $\mathrm{h}^{-1}$ (all time points, $n=32$; Table 7 ). Potential nitrogen fixation was detected at $T=0$ (one of eight samples, $0.13 \mathrm{ng} \mathrm{N} \mathrm{g}^{-1}$ $\mathrm{h}^{-1}$ ) and $T+10$ (four of eight samples, ranging from 0.04 to $0.50 \mathrm{ng} \mathrm{N} \mathrm{g}^{-1} \mathrm{~h}^{-1}$ ) (Table 7). No potential nitrogen fixation was detected at $T+3$ and $T+5$ (Table 6). Potential nitrogen fixation was only detected when $\mathrm{TN}_{(\mathrm{aq})}$ was $\leq 9 \mu$ moles $\mathrm{L}^{-1}$, and $\mathrm{TN}_{\mathrm{KCl}}$ was $\leq 330 \mathrm{ng} \mathrm{N} \mathrm{g}^{-1}$ (Figure 4).

There was no significant $(p<0.05)$ correlation between bacterial production and potential photosynthesis $(R=0.108, p=$ $0.562, n=32$, not shown). There was a significant correlation of bacterial production with $\delta^{18} \mathrm{O}-\mathrm{H}_{2} \mathrm{O}(R=-0.40, p<0.05$, $n=32)$ but not between potential photosynthesis and $\delta^{18} \mathrm{O}-\mathrm{H}_{2} \mathrm{O}$ $(R=-0.11, p=0.549, n=32)$ (Figure 1). There was a weak but significant correlation between DIC and photosynthesis (Pearson correlation, $R=0.45, p<0.05$; Figure 5).

\section{BIOGEOCHEMISTRY AS A FUNCTION OF ISOLATION AGE}

The estimated mean isolation age (from the supraglacial water system) of the cryoconite holes $(T=0$ and $T+10)$ from chloride mass balance was $3.4 \pm 3.6(1 \sigma)$ years (Table 1). There were significant increases in the mass of solute per unit area for $\mathrm{Cl}^{-}$ $\left(R^{2}=0.955, p<0.0005, n=16\right), \mathrm{Na}^{+}\left(R^{2}=0.824, p<0.0005\right.$, $n=16), \mathrm{K}^{+}\left(R^{2}=0.686, p<0.0005\right), \mathrm{Mg}^{2+}\left(R^{2}=0.647, p<\right.$ $0.0005, n=32), \mathrm{Ca}^{2+}\left(R^{2}=0.613, p<0.0005, n=16\right)$ and 

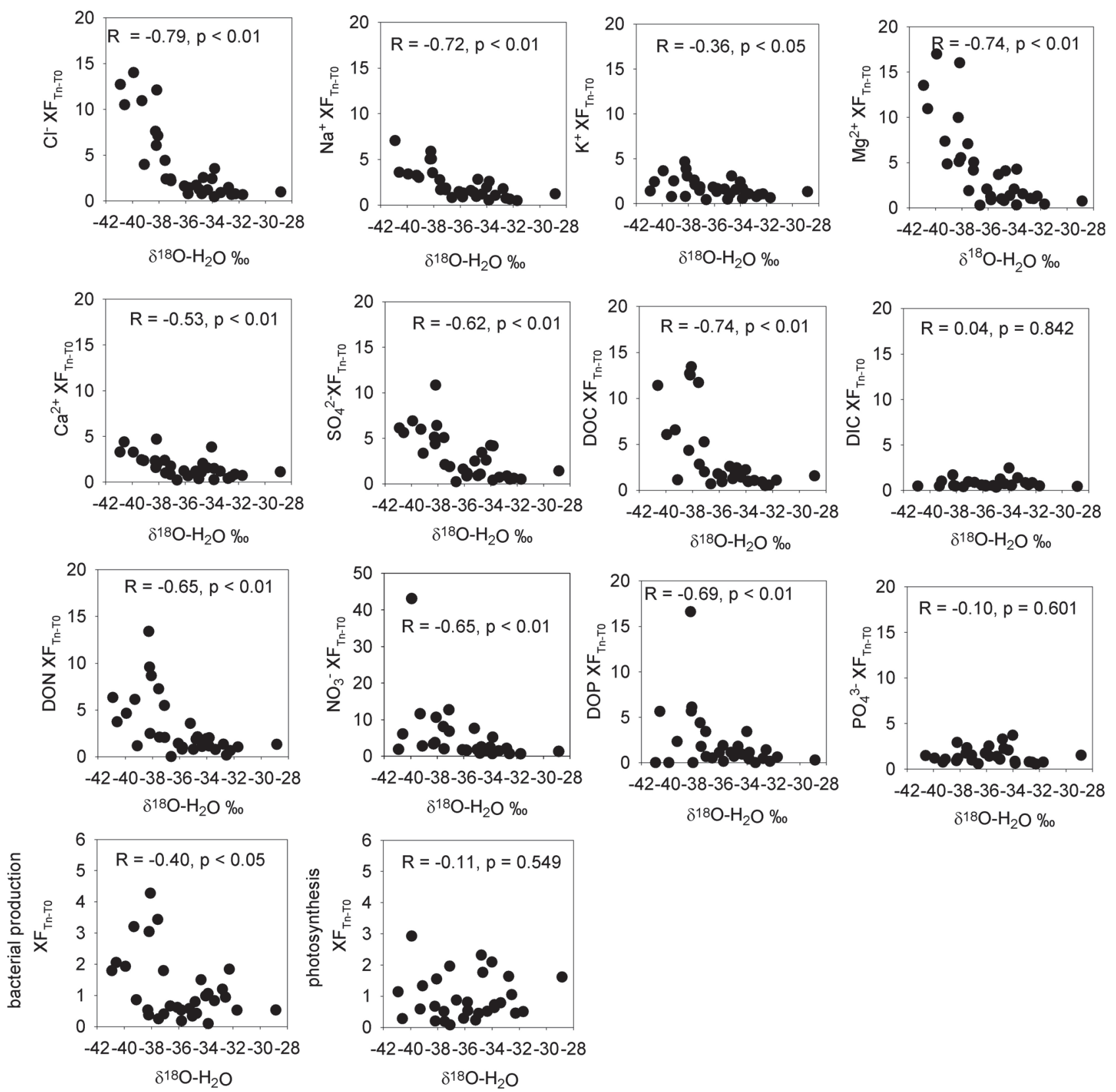

FIGURE 1 | Enrichment factors (XF) for aqueous ions and cryoconite bacterial production and photosynthesis vs. $\delta^{18} \mathrm{O}-\mathrm{H}_{2} \mathrm{O}$ (a measure of the $\%$ ice melt). Enrichment factors are the ratio of the measured aqueous concentrations of the ion to the mean concentration of that ion in initial frozen cryoconite holes. Statistics refer to Pearson correlation coefficients after taking the logarithm of the enrichment factor.
$\mathrm{SO}_{4}^{2-}\left(R^{2}=0.688, p<0.0005, n=16\right)$ with increasing isolation age (Figure 6). There were also significant increases in the mass of solute per unit area for DOC $\left(R^{2}=0.405, p=0.008, n=16\right)$, DON $\left(R^{2}=0.279, p=0.035, n=16\right)$, DIN $\left(R^{2}=0.821, p=\right.$ $0.0005, n=14$ with two below detection outliers removed), DOP $\left(R^{2}=0.463, p=0.004, n=16\right)$ and $\mathrm{PO}_{4}^{3-}\left(R^{2}=0.406, p=\right.$ $0.008, n=16$ ) with increasing isolation age of the holes. In contrast, there were no significant $(p<0.05)$ relationships between isolation age and DON:DIN $\left(R^{2}=0.024, p=0.274, n=16\right)$,
DOP:PO ${ }_{4}^{3-}\left(R^{2}=0.001, p=0.913\right), \mathrm{P}_{\mathrm{MgCl} 2}\left(R^{2}=0.000, p=\right.$ $0.988), \mathrm{P}_{\mathrm{NaOH}}\left(R^{2}=0.007, p=0.773\right), \mathrm{P}_{\text {residual }}\left(R^{2}=0.001\right.$, $\left.R^{2}=0.929\right)$ or $\mathrm{N}_{\mathrm{KCl}}\left(R^{2}=0.105, p=0.259\right)$ (not shown), bacterial production $\left(\mathrm{R}^{2}=0.001, p=0.913\right)$ or photosynthesis $\left(R^{2}=\right.$ $0.073, p=0.325)$ (Figure 6).

\section{NUTRIENT MASS BALANCE WITHIN CRYOCONITE HOLES}

Nutrient fluxes from ice ablation into Canada Glacier cryoconite holes can account for means of $70 \%$ of the organic carbon 


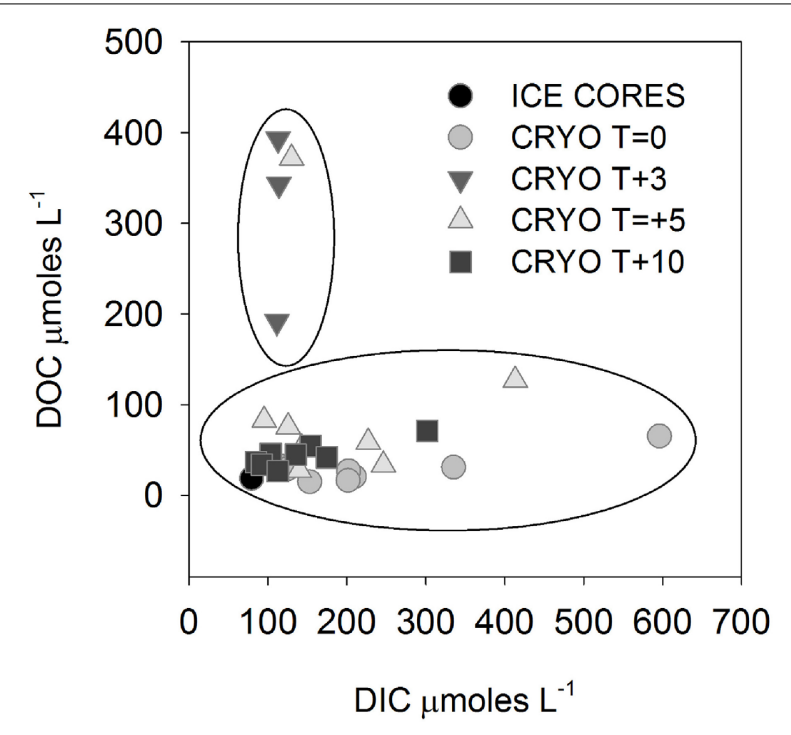

FIGURE 2 | Dissolved inorganic carbon (DIC) vs. dissolved organic carbon (DOC) in cryoconite hole waters. Note that all $T+3$ and one $T+5$ samples are outliers to the remainder of the samples.

Table 4 | Dissolved nutrient ratios in ice cores and cryoconite holes.

\begin{tabular}{lccccc}
\hline & C:N & C:P & N:P & DON:DIN & DOP:PO $\mathbf{4}$ \\
\hline Ice cores & $4.5 \pm 1.3$ & $218 \pm 137$ & $46.8 \pm 24.9$ & $1.9 \pm 1.2$ & $0.6 \pm 0.2$ \\
$T=0$ & $7.4 \pm 2.0$ & $299 \pm 110$ & $45.4 \pm 25.7$ & $1.4 \pm 0.9$ & $0.7 \pm 0.5$ \\
$T+3$ & $9.6 \pm 6.8$ & $831 \pm 199$ & $101 \pm 62$ & $1.2 \pm 1.2$ & $2.9 \pm 1.1$ \\
$T+5$ & $5.9 \pm 3.9$ & $348 \pm 230$ & $76.1 \pm 59.6$ & $2.8 \pm 3.5$ & $4.9 \pm 7.3$ \\
$T+10$ & $7.6 \pm 1.3$ & $268 \pm 73$ & $36.8 \pm 12.4$ & $1.9 \pm 1.3$ & $0.4 \pm 0.2$ \\
\hline
\end{tabular}

Uncertainty is $1 \sigma(n=8)$

demand, $80 \%$ of the nitrogen demand, and $22 \%$ of the phosphorus demand of bacterial production (Table 8). Ablation nutrient fluxes account for means of $36 \%$ of the dissolved inorganic carbon demand of photosynthesis, $11 \%$ of the nitrogen demand and just $2 \%$ of the phosphorus demand (Table 8 ).

We calculate that in holes where potential nitrogen fixation was detected, nitrogen fixation could account for a mean of $12.3 \pm$ $13.3 \%$ of the estimated carbon production of photosynthesis, or $119 \pm 177 \%$ of bacterial production.

\section{DISCUSSION \\ MICROBIAL BIOGEOCHEMICAL CYCLING IN ENTOMBED CRYOCONITE HOLES}

The air temperature above Canada Glacier in the 2011 season is shown in Figure 7 [data from Fountain, www.mcmlter. org/queries/met/met_stations.jsp\#CAAM]. The air temperature was consistently below $0^{\circ} \mathrm{C}$ for the period of this study (mean $-4.8^{\circ} \mathrm{C}$ ), and below $0^{\circ} \mathrm{C}$ for all but a few days of the entire melt season (Figure 7). Despite the subzero temperatures during the study period, the presence of liquid water in holes from $T+3$ (Table 1) demonstrates that incoming solar radiation through the ice lids was sufficient to warm the cryoconite sediment enough to melt ice (Mueller et al., 2001; Fountain et al., 2004, 2008; Hoffman et al., 2008).

The chemistry of the ice cores and fully frozen cryoconite holes are similar to those described on Canada Glacier in previous melt seasons (Tranter et al., 2004; Bagshaw et al., 2007), and provide evidence for mineral dissolution reactions and active microbial nutrient cycling. The mean isolation age of 3.4 years was within the previously reported ranges of 0-11 years (Fountain et al., 2004; Tranter et al., 2004) and 0-5 years (Bagshaw et al., 2007). Relative to concentrations in surrounding ice, the enrichment of dissolved $\mathrm{Ca}^{2+}, \mathrm{Mg}^{2+}$, and $\mathrm{SO}_{4}^{2-}$ over $\mathrm{Cl}^{-}$(Table 3) most likely indicates the dissolution of rock debris within the enclosed cryoconite holes (Tranter et al., 2004). The lower mean enrichment factors for aqueous nitrogen species ( $\mathrm{DON}, \mathrm{NO}_{3}^{-}, \mathrm{NO}_{2}^{-}$) and phosphorus species (DOP and $\mathrm{PO}_{4}^{3-}$ ) relative to $\mathrm{Cl}^{-}$are consistent with the microbiological uptake of nutrients (Tranter et al., 2004).

Our results are consistent with a relationship of increasing aqueous nutrient mass with age (Tranter et al., 2004; Bagshaw et al., 2007). There were significant increases in aqueous inorganic ions $\left(\mathrm{Cl}^{-}, \mathrm{Na}^{+}, \mathrm{Ca}^{2+}, \mathrm{Mg}^{2+}, \mathrm{SO}_{4}^{2-}\right.$, all $\left.p<0.0005\right)$ and nutrients (TOC, TON, TIN, DOP, and $\mathrm{PO}_{4}^{3-}$, all $p<0.01$ other than TON with $p<0.05)$ with increasing isolation age of the holes (Figure 6). While it might be argued that rates of bacterial production and photosynthesis should also increase with greater isolation age due to the higher nutrient load, we found no such significant relationships $(p>0.05)$. It is possible that trends could be masked by the high natural variation in microbial activity rates in individual samples (Figure 6), or by limitation by some other factor (e.g., temperature, or DIC in the case of photosynthesis). Alternatively, it may be that the aqueous concentration of nutrients in the cryoconite hole water column at the time of measurement may be a more important factor than the total mass of nutrients within the cryoconite hole for determining short term microbial activity rates. The impact of freeze-thaw concentration effects on rates of microbial activity is discussed in greater detail in Section Impact of Ionic Pulses on Cryoconite Hole Biogeochemistry.

The cell counts and cell biomass estimates (Table 6) support the presence of a mixed microbial assemblage of both heterotrophs and phototrophs, consistent with previous studies (Christner et al., 2003; Foreman et al., 2007). Autoflourescent cell counts confirmed the presence of a substantial population of phototrophs within the cryoconite sediments (Table 6). The mean measured rates of bacterial production $(2.4 \pm 1.6 \mathrm{ng} \mathrm{C}$

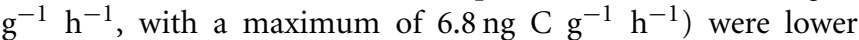
than the mean reported for cryoconite holes from a range of MDV glaciers $\left(23.4 \pm 11.8 \mathrm{ng} \mathrm{C} \mathrm{g}^{-1} \mathrm{~h}^{-1}\right.$; Canada Glacier, Commonwealth Glacier, and Taylor Glacier) (Anesio et al., 2010). This may reflect the higher organic matter contents of cryoconite on Commonwealth Glacier relative to Canada Glacier (Bagshaw et al., 2013). The mean rate of photosynthesis in cryoconite in this study $\left(15.3 \pm 11.7 \mathrm{ng} \mathrm{C} \mathrm{g}^{-1} \mathrm{~h}^{-1}\right.$, with a maximum of $48 \mathrm{ng} \mathrm{C} \mathrm{g}^{-1}$ $\mathrm{h}^{-1}$ ) are similar to those reported previously from Canada Glacier using the ${ }^{14} \mathrm{C}$ method of $17-58 \mathrm{ng} \mathrm{C} \mathrm{g}^{-1} \mathrm{~h}^{-1}$ (reported in Hodson et al., 2013) and $34 \mathrm{ng} \mathrm{C} \mathrm{g}^{-1} \mathrm{~h}^{-1}$ using a $\Delta \mathrm{O}_{2}$ method (Bagshaw et al., 2011), although $4 \times$ lower than mean rates in entombed 

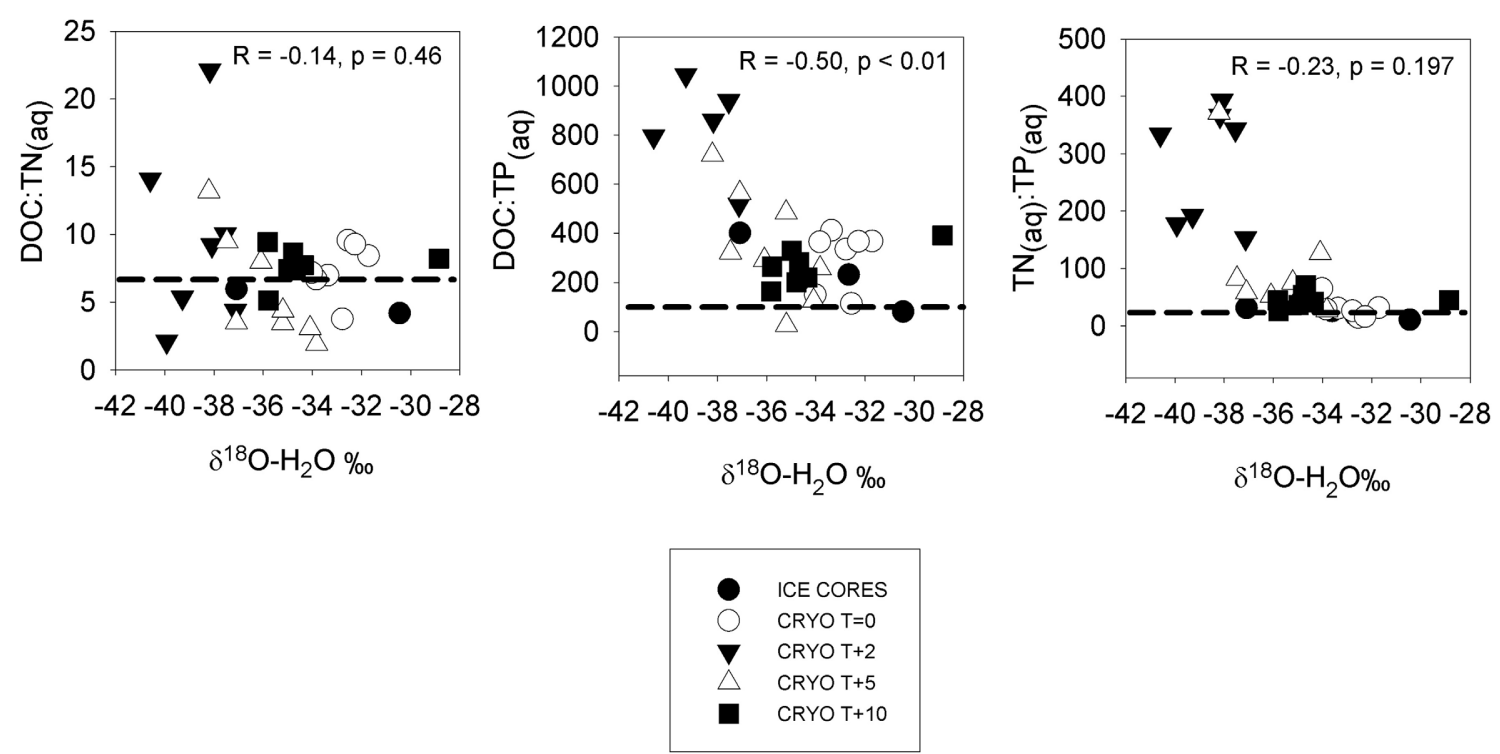

FIGURE 3 | Dissolved nutrient ratios in ice cores and cryoconite hole waters vs. $\delta^{18} \mathrm{O}-\mathrm{H}_{2} \mathrm{O}$ (a measure of the \% ice melt). Dotted horizontal lines show the Redfield ratios. Statistics refer to Pearson correlation coefficients.

Table 5 | Cryoconite solid phase nutrients.

\begin{tabular}{|c|c|c|c|c|c|c|c|c|}
\hline & $\begin{array}{c}\text { TOC } \\
\mathbf{m g ~ C ~}^{-1}\end{array}$ & $\begin{array}{c}\text { IC } \\
\mathrm{mg} \mathrm{C} \mathrm{g}^{-1}\end{array}$ & 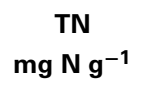 & $\begin{array}{c}\mathrm{NH}_{4}^{+} \mathrm{KCl} \\
\mathrm{ng} \mathrm{N} \mathrm{g}^{-1}\end{array}$ & $\begin{array}{c}\mathrm{NO}_{3}^{-} \mathrm{KCl} \\
\mathbf{n g ~ N ~ g}\end{array}$ & $\begin{array}{c}\mathbf{P}_{\mathrm{MgCl} 2} \\
\mu \mathbf{P ~}^{-1}\end{array}$ & $\begin{array}{c}\mathbf{P}_{\mathrm{NaOH}} \\
\mu \mathbf{g ~} \mathbf{P ~ g}^{-1}\end{array}$ & $\begin{array}{c}\mathbf{P}_{\text {residual }} \\
\mu \mathbf{g ~ P ~ g}^{-1}\end{array}$ \\
\hline$T=0$ & $1.2 \pm 0.4$ & $0.8 \pm 0.4$ & Detected & $85 \pm 101$ & $\mathrm{BDL}$ & $0.9 \pm 1.2$ & $8.3 \pm 1.4$ & $1403 \pm 330$ \\
\hline$T+5$ & $0.9 \pm 0.6$ & $0.3 \pm 0.1$ & $\mathrm{BDL}$ & $487 \pm 404$ & $46 \pm 32$ & $\mathrm{BDL}$ & $10.9 \pm 2.3$ & $1516 \pm 109$ \\
\hline$T+10$ & $0.9 \pm 0.4$ & $0.5 \pm 0.3$ & Detected & $316 \pm 274$ & $3.1 \pm 8.4$ & $0.3 \pm 0.7$ & $10.0 \pm 1.5$ & $1493 \pm 70$ \\
\hline Mean & $0.9 \pm 0.4$ & $0.5 \pm 0.3$ & & $451 \pm 490$ & $20 \pm 29$ & $0.5 \pm 1.2$ & $10.3 \pm 3.4$ & $1455 \pm 241$ \\
\hline
\end{tabular}

Uncertainty is $1 \sigma(n=3$ for TOC, $I C$ and $T N, n=8$ for remainder).

Table 6 | Cryoconite cells counts and biomass estimates.

\begin{tabular}{|c|c|c|c|c|c|c|c|}
\hline & $\begin{array}{c}\text { DAPI (total cell) } \\
\text { counts Cells } \mathbf{g}^{-1} \text { wet }\end{array}$ & $\begin{array}{l}\text { Autoflourescent (AF) } \\
\text { cell counts } \mathrm{g}^{-1} \text { wet }\end{array}$ & $\begin{array}{c}\text { DAPI } \\
\text { volume } \mu \mathrm{m}^{3}\end{array}$ & $\begin{array}{c}\text { AF volume } \\
\mu \mathrm{m}^{3}\end{array}$ & $\begin{array}{l}\% \text { AF } \\
\text { counts }\end{array}$ & $\begin{array}{l}\text { DAPI biomass } \\
\mu \mathrm{g} \mathrm{C} \mathrm{g}^{-1} \text { wet }\end{array}$ & $\begin{array}{l}\text { AF biomass } \\
\mu \mathrm{g} \mathrm{C} \mathrm{g}^{-1} \text { wet }\end{array}$ \\
\hline$T=0$ & $8.0 \times 10^{8} \pm 2.0 \times 10^{8}$ & $5.0 \times 10^{7} \pm 3.1 \times 10^{7}$ & $0.11 \pm 0.03$ & $0.07 \pm 0.04$ & $5.8 \pm 2.9$ & $19.6 \pm 5.4$ & $0.9 \pm 0.8$ \\
\hline$T+3$ & $5.9 \times 10^{8} \pm 1.2 \times 10^{8}$ & $8.2 \times 10^{7} \pm 4.1 \times 10^{7}$ & $0.06 \pm 0.04$ & $0.61 \pm 0.65$ & $15.0 \pm 9.1$ & $7.6 \pm 4.2$ & $14.4 \pm 20.3$ \\
\hline$T+5$ & $6.8 \times 10^{8} \pm 0.76 \times 10^{8}$ & $4.5 \times 10^{7} \pm 0.65 \times 10^{7}$ & $0.05 \pm 0.01$ & $0.17 \pm 0.14$ & $6.7 \pm 0.2$ & $6.9 \pm 1.3$ & $1.6 \pm 1.1$ \\
\hline$T+10$ & $7.0 \times 10^{8} \pm 2.7 \times 10^{8}$ & $8.8 \times 10^{7} \pm 3.9 \times 10^{7}$ & $0.08 \pm 0.04$ & $0.32 \pm 0.16$ & $1.2 \pm 5.5$ & $16.5 \pm 6.0$ & $6.4 \pm 3.1$ \\
\hline Mean & $7.0 \times 10^{8} \pm 1.4 \times 10^{8}$ & $7.0 \times 10^{7} \pm 3.5 \times 10^{7}$ & $0.08 \pm 0.04$ & $0.32 \pm 0.42$ & $10.6 \pm 6.8$ & $12.8 \pm 7.0$ & $6.8 \pm 12.3$ \\
\hline
\end{tabular}

Uncertainty is $1 \sigma(n=3)$.

cryoconite holes at Vestfold Hills, Antarctica (92 $\pm 63 \mathrm{ng} \mathrm{C} \mathrm{g}^{-1}$ $\mathrm{h}^{-1}$ ) (Hodson et al., 2013).

If we assume that the disparity between the mean organic carbon content of MDV valley floor soil $\left(0.2 \mathrm{mg} \mathrm{C} \mathrm{g}^{-1}\right.$; Barrett et al., 2007) and Canada Glacier cryoconite $\left(0.9 \mathrm{mg} \mathrm{C} \mathrm{g}^{-1}\right.$; Table 5$)$ is attributable to net photosynthesis (Bagshaw et al., 2013), then the measured rates of photosynthesis can be used to place some constraints on the possible residence time of cryoconite debris on the surface of the glacier. This seems a reasonable assumption, given that aeolian organic matter derived from the valley floor and deposited onto the glaciers has a lower rather than higher organic matter content than valley soils (Sabacka et al., 2012). The amount of organic matter that would be produced by the mean and maximum rates of photosynthesis rates from this study were $15.3 \mathrm{ng} \mathrm{C} \mathrm{g}^{-1} \mathrm{~h}^{-1}$ and $47.8 \mathrm{ng} \mathrm{C} \mathrm{g}^{-1} \mathrm{~h}^{-1}$ respectively, equivalent to $26 \mu \mathrm{g} \mathrm{C} \mathrm{g}^{-1}$ and $80 \mu \mathrm{g} \mathrm{C} \mathrm{g}^{-1}$ over a 10 
week melt season. To make up the $700 \mu \mathrm{g} \mathrm{C} \mathrm{g}^{-1}$ deficit between MDV soils and Canada glacier cryoconite would require 27 years and 9 years, respectively at these mean and maximum rates of photosynthesis, greater than the 3.4 year mean isolation age of the cryoconite holes. In reality, rates of net autochthonous organic accumulation will be substantially lower than measurements of gross photosynthesis in cryoconite holes, as respiration is likely to recycle a significant fraction of the autotrophic carbon (Telling et al., 2012a; Hodson et al., 2013). Assuming that the rates of photosynthesis measured in this study are representative, the relatively high organic content of the cryoconite could be explained by the cryoconite being trapped within holes on the glacier for several decades, far greater than the average residence time of water within the cryoconite holes. The longer residence time of cryoconite debris over cryoconite water on the glaciers provides a potential explanation for the lack of any trends between cryoconite debris nutrient concentration and the isolation age of the holes (Section Biogeochemistry as a Function of Isolation Age). The cryoconite debris nutrient concentrations may instead reflect the sum of their history in contact with water of a variety of different isolation ages.

Mass balance estimates indicate that nutrient fluxes $(\mathrm{C}, \mathrm{N}$, P) from ice ablation alone are unlikely to be able to sustain the

Table 7 | Rates of microbial activity in cryoconite.

\begin{tabular}{|c|c|c|c|c|}
\hline & $\begin{array}{c}\text { Bacterial } \\
\text { production } \\
\mathbf{n g ~ C ~ g - 1 ~} \mathbf{h}^{-1}\end{array}$ & $\begin{array}{l}\text { Photosynthesis } \\
\qquad n g \text { g g }^{-1} h^{-1}\end{array}$ & $\begin{array}{c}\text { Nitrogen } \\
\text { fixation } \\
\text { ng N g } \mathbf{~ g}^{-1} \mathbf{h}^{-1}\end{array}$ & $\begin{array}{c}\text { Nitrogen } \\
\text { fixation } \\
\mu \text { moles } \\
\mathrm{C}_{2} \mathrm{H}_{4} \mathbf{m}^{-2} \mathrm{~d}^{-1}\end{array}$ \\
\hline$T=0$ & $3.7 \pm 1.5$ & $16.3 \pm 9.4$ & $0.02 \pm 0.05$ & $<1-2.3$ \\
\hline$T+3$ & $10.0 \pm 3.4$ & $18.6 \pm 15.6$ & $\mathrm{BDL}$ & $<1$ \\
\hline$T+5$ & $1.7 \pm 0.9$ & $8.1 \pm 7.2$ & $B D L$ & $<1$ \\
\hline$T+10$ & $2.0 \pm 1.6$ & $17.3 \pm 11.9$ & $0.15 \pm 0.20$ & $<1-4.9$ \\
\hline
\end{tabular}

Uncertainty is $1 \sigma(n=8)$. measured rates of microbial activity, even with efficient recycling between the heterotrophic and autotrophic communities (Table 8). Particulate inorganic and organic matter in cryoconite debris can provide additional sources of nutrients to cryoconite ecosystems that can help make up the deficit from ice melt (Foreman et al., 2007; Stibal et al., 2008, 2009). While concentrations of loosely adsorbed phosphorus $\left(\mathrm{P}_{\mathrm{MgCl} 2}\right)$ were close to the detection limit (Table 5) consistent with previous studies on the glacier (Bagshaw et al., 2013) there were higher concentrations of potentially bioavailable inorganic $\mathrm{P}_{\mathrm{NaOH}}$ (mean of $10.3 \pm 3.4 \mu \mathrm{g}$ $\mathrm{P} \mathrm{g}^{-1}$ ). The majority of phosphorus in cryoconite was in the form of $\mathrm{P}_{\text {residual }}$ (mean of $1455 \pm 241 \mu \mathrm{g} \mathrm{P} \mathrm{g}^{-1}$ ), of which approximately $40 \%$ may be in the form of organic phosphorus (Bagshaw et al., 2013). The microbial uptake of phosphorus from organic matter in Canada Glacier cryoconite holes is consistent with the previous detection of phosphatase enzyme activity (Foreman et al., 2007). Additional DIC can derive from carbonate dissolution and organic matter remineralization (Tranter et al., 2004). This is consistent with entombed cryoconite hole biogeochemistry at a blue ice Antarctic site (Vestfold Hills) where rates of DIC inputs from ice ablation into entombed cryoconite holes were insufficient to account for all of the measured rates of net ecosystem production (Hodson et al., 2013).

The detection of potential nitrogen fixation in fully melted cryoconite holes $(T=0$ and $T+10$; Table 7$)$ suggests that the combination of ice ablation and the recycling of allochthonous organic matter was not always sufficient to meet the full nitrogen requirements of microbial growth. Nitrogen fixation may make up the deficit and ensure that dissolved DOC:TN ratios remain relatively close to those of the Redfield ratio (Figure 3). The rates of areal potential nitrogen fixation measured in the ice lidded cryoconite holes $\left(<1.0-7.9 \mu\right.$ moles $\left.\mathrm{C}_{2} \mathrm{H}_{4} \mathrm{~m}^{-2} \mathrm{~d}^{-1}\right)$ were similar to those measured in open cryoconite holes on a Greenland glacier of $<4.2-16.3 \mu$ moles $\mathrm{C}_{2} \mathrm{H}_{4} \mathrm{~m}^{-2} \mathrm{~d}^{-1}$ (Telling et al., 2012b) although lower than the maximum rates measured on Svalbard valley glaciers of $100 \mu$ moles $\mathrm{C}_{2} \mathrm{H}_{4} \mathrm{~m}^{-2} \mathrm{~d}^{-1}$ (Telling et al., 2011). Nitrogen fixation could therefore be a
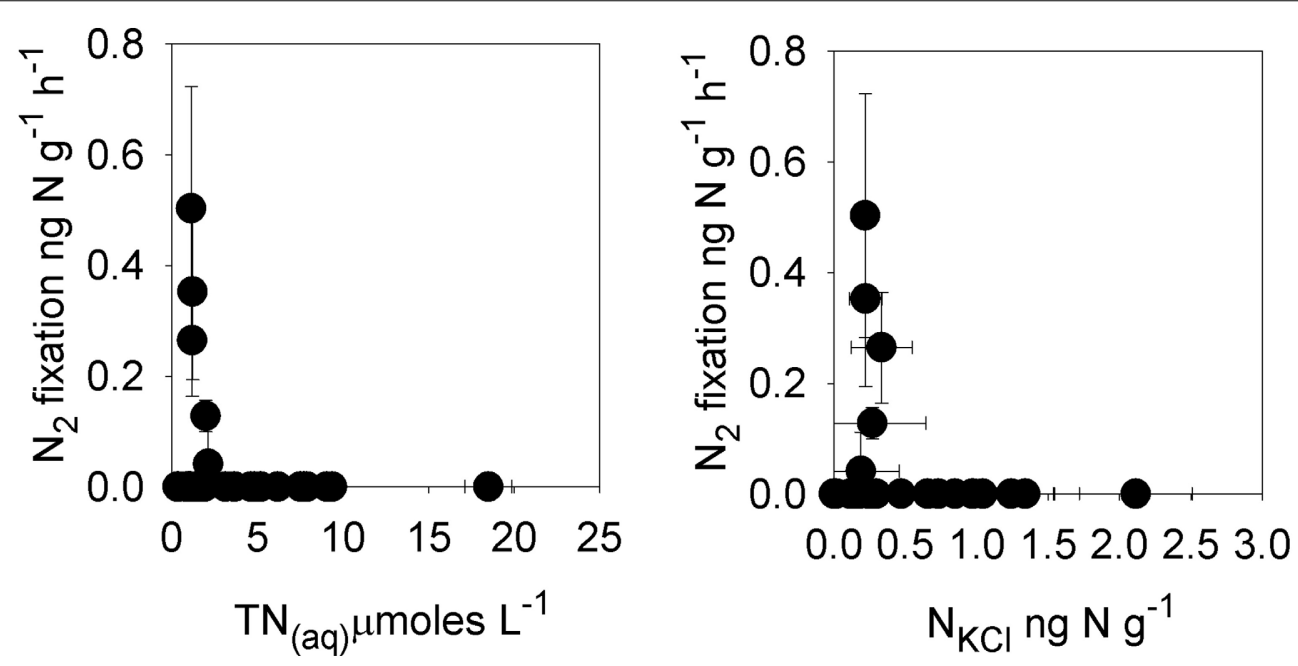

FIGURE 4 | Rates of potential nitrogen fixation in cryoconite vs. total dissolved nitrogen $\left(\operatorname{TN}_{(\mathrm{aq})}\right)$ and cryoconite bound exchangeable nitrogen $\left(\mathrm{N}_{\mathrm{KCI}}\right)$. 


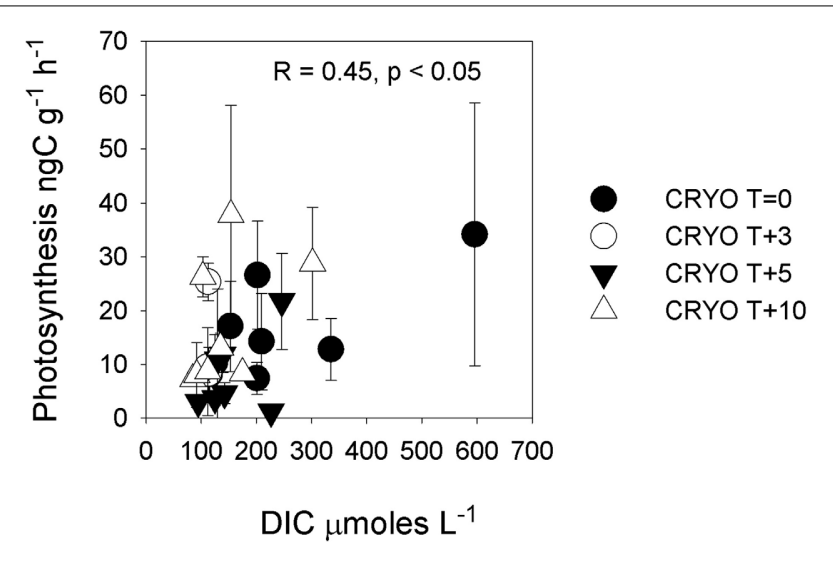

FIGURE 5 | Rate of photosynthesis in cryoconite vs. dissolved inorganic carbon (DIC). Statistics refer to Pearson correlation. Note that the significance of the relationship disappears when the highest DIC sample is removed.

significant additional source of nitrogen for microbial growth during the main melt season away from more nitrogen rich ionic pulses (see below), where it could potentially account for $100 \%$ of the nitrogen demand of bacterial production and $12 \%$ of the nitrogen demand of photosynthesis (Section Nutrient Mass Balance within Cryoconite Holes). When cryoconite is periodically flushed downstream during warmer high melt events (Fountain et al., 2004; Foreman et al., 2007; Bagshaw et al., 2013) nitrogen derived from supraglacial nitrogen fixation will contribute to nutrient fluxes to proglacial streams and perennially ice covered lakes.

\section{IMPACT OF IONIC PULSES ON CRYOCONITE HOLE BIOGEOCHEMISTRY}

Relative to frozen cryoconite holes at $T=0$, the increase in mean $\mathrm{Cl}^{-}$concentrations $>9 \times$ during the initial melting $(T+3)$ of cryoconite holes coincident with more negative $\delta^{18} \mathrm{O}-\mathrm{H}_{2} \mathrm{O}$ (Table 2) is consistent with an ionic pulse; the concentration of ions due to the initial melting of brine ice created during freeze up the previous melt season (Fountain et al., 2008). The mean enrichment factors for different ions varied during the ionic pulse (Figure 1), ranging from $0.5 \times$ for DIC to $10.2 \times$ for $\mathrm{Mg}^{2+}$. One possible explanation for the variation in the enrichment factors for different ions could be that they have different partition coefficients from/into the ice crystal structure during freeze-thaw events. The relative order of ion enrichment in the cryoconite hole ionic pulse (Table 3 ) is however different to that reported for early snow melt (Cragin et al., 1996). For example, in the early melt cryoconite holes $(T+3) \mathrm{Cl}^{-}$has the second largest enrichment factor after $\mathrm{Mg}^{2+}$ (excluding $\mathrm{C}, \mathrm{N}$, and $\mathrm{P}$; see below) (Table 3) whereas $\mathrm{Cl}^{-}$has the lowest enrichment factor in early snow melt (Cragin et al., 1996). The reason for these differences is unclear and deserves further research. Potential explanations include differences in freezing rates (e.g., a higher freezing rate could result in lower fractionation factors) or variations in solute concentration/speciation. In addition, mineral precipitation reactions may influence the concentrations of ions such as $\mathrm{Ca}^{2+}$ and
DIC (see below), while microbial activity could influence the concentrations of $\mathrm{C}, \mathrm{N}$, and $\mathrm{P}$ species.

The behavior of the macronutrients $\mathrm{C}, \mathrm{N}$, and $\mathrm{P}$ during the ionic pulse is important as they could directly impact microbial activity. The mean enrichment factors for DOC $(9.6 \times)$, $\mathrm{NH}_{4}^{+}(9.7 \times)$, and $\mathrm{NO}_{2}^{-}(9.7 \times)$ were similar to $\mathrm{Cl}^{-}(9.3 \times)$ (Figure 1), suggesting a dominant control by freeze-thaw processes. The lower mean enrichment factor for DON $(5.6 \times)$ and higher enrichment factor for $\mathrm{NO}_{3}^{-}(12.2 \times)$ (Figure 1) suggest a short term perturbation of the ecosystem with the temporary increased microbial utilization of dissolved organic nitrogen and nitrification during the ionic pulse. The lack of detectable nitrogen fixation during the ionic pulse $(T+3$ and $T+5$; Table 7$)$ is likely due to the relatively high concentrations of both dissolved and cryoconite bound nitrogen species during the ionic pulse event (Figure 4, Table 5), analogous to the inhibition of nitrogen fixation by relatively nitrogen rich snow melt in open cryoconite holes in the Arctic (Telling et al., 2011).

The ionic pulse was associated with significantly $(p<0.05)$ increased rates of bacterial production (Figure 1), alongside a substantial increase in cryoconite bound $\mathrm{NH}_{4}^{+} \mathrm{KCl}$ (Table 5) indicative of increased organic matter remineralization. The enrichment factors for $\mathrm{PO}_{4}^{3-}(1.1 \times)$ and DOP $(4.4 \times)$ during the ionic pulse were lower than for DOC and dissolved nitrogen species, resulting in higher TOC: $\mathrm{TP}_{(\mathrm{aq})}$ and $\mathrm{TN}: \mathrm{TP}(\mathrm{aq})$ ratios (Figure 3). The dissolved nutrient stoichiometry suggests that the primary explanation for the elevated rates of bacterial production during the ionic pulse may be an alleviation of phosphorus limitation, with the preferential uptake of $\mathrm{PO}_{4}^{3-}$ over DOP (Figure 1). The lack of nitrogen fixation during the ionic pulse (Table 7) could potentially contribute to the elevated rates of bacterial production as nitrogen fixation is typically energetically expensive relative to the uptake of dissolved nitrogen (Gutschick, 1978).

Unlike bacterial production, rates of potential photosynthesis were not significantly $(p>0.05)$ elevated during the ionic pulse (Figure 1). Within cryoconite holes, a contributing factor could be light limitation due to shading by either the ice and lid surrounding the hole (Hodson et al., 2013) or by cryoconite grains. While no attempt was made in this study to replicate the exact light levels within the in situ cryoconite holes, previous studies on Arctic cryoconite have demonstrated significant selfshading by cryoconite grains in sediment $>1 \mathrm{~mm}$ thick (Cook et al., 2010; Telling et al., 2012a). Given that the mean sediment thickness in the Canada glacier cryoconite holes and incubations was $>5 \mathrm{~mm}$ (Table 1), it seems highly likely that at least some degree of light limitation was present in situ if sediment depth integrated rates of photosynthesis are considered. The ultimate limiting factor for photosynthesis in these entombed cryoconite holes may however be DIC. In contrast to all other measured dissolved species, there was a mean net depletion $(0.5 \times)$ rather than enrichment in mean DIC concentrations during the ionic pulse event (Table 3, Figure 1). Although DIC was measured on only three cryoconite holes during the ionic pulse event due to low water levels in the holes at this time, the similarity of all three measurements suggests that this is a real geochemical feature (Figure 2). The available data is consistent with inorganic 


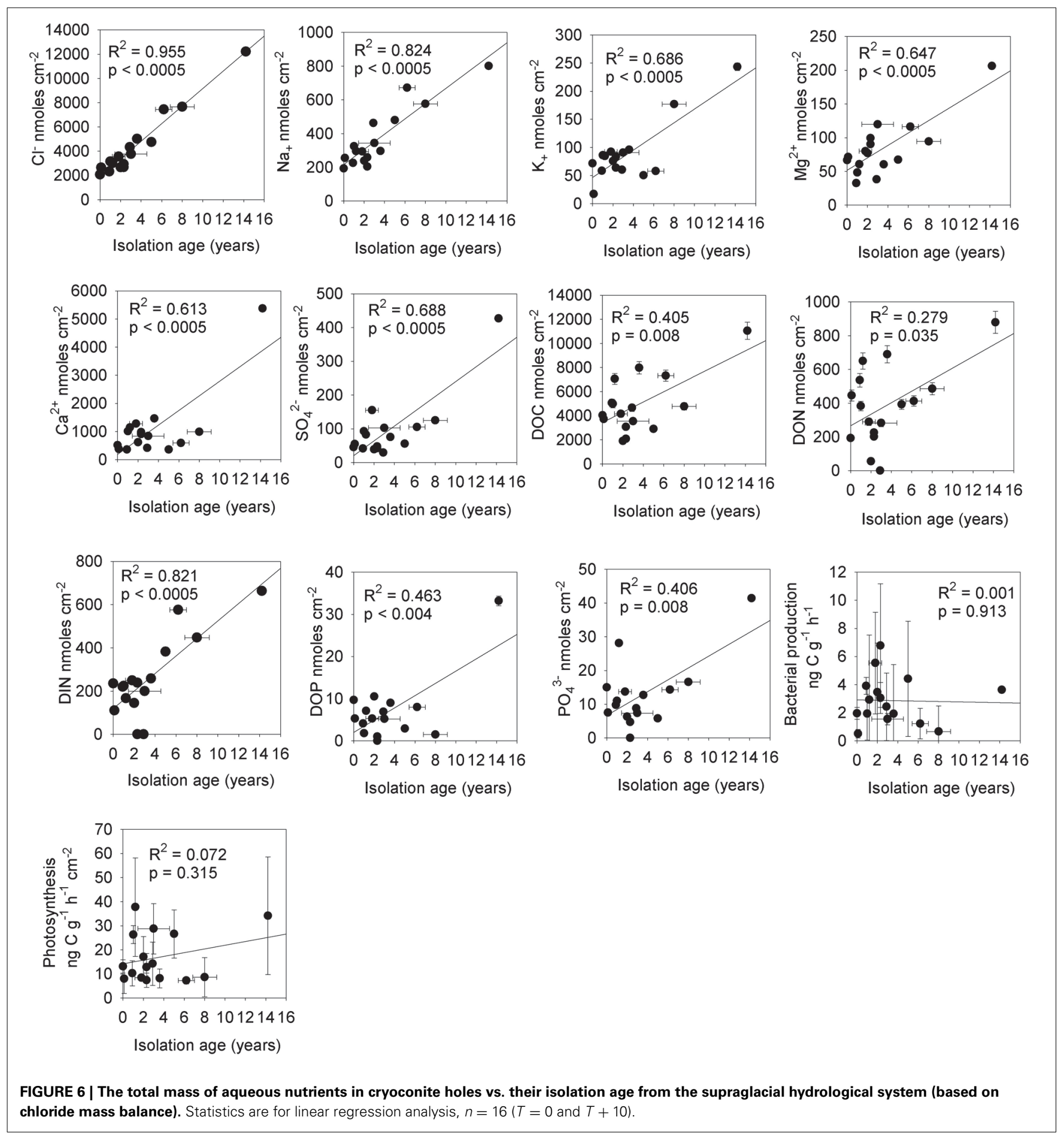

carbon limitation of photosynthesis within the cryoconite holes. The $\mathrm{CO}_{2(\mathrm{aq})}$ concentrations of this study $(T+10$ only) ranged from 0.05 to $12.9 \mu$ moles $\mathrm{L}^{-1}$, with a mean of $2.6 \mu$ moles $\mathrm{L}^{-1}$. Freshwater phototrophs typically have a higher affinity for $\mathrm{CO}_{2}$ than $\mathrm{HCO}_{3}^{-}$(Hein, 1997) with many species unable to make use of $\mathrm{HCO}_{3}^{-}$directly (Maberly and Spence, 1983). In a review of the inorganic carbon uptake kinetics of 25 freshwater species of phytoplankton, $\mathrm{K}_{1 / 2}$ values ranged from 0.1 to $170 \mu$ moles $\mathrm{L}^{-1}$
$\mathrm{CO}_{2(\mathrm{aq})}$, with a median of $13 \mu$ moles $\mathrm{L}^{-1}$ (Hein, 1997). This median value is higher than all values of $\mathrm{CO}_{2(\mathrm{aq})}$ in cryoconite holes at $\mathrm{T}+10$. There is also a weak but significant correlation $(p<0.05)$ between DIC and rates of photosynthesis (Figure 5), although this correlation is not significant if the single highest rate of photosynthesis is removed. Inorganic carbon limitation of photosynthesis within the entombed cryoconite holes therefore appears plausible, but further research is needed to quantify 
Table 8 | Estimated nutrient fluxes into $T=0$ and $T+10$ cryoconite holes from ice ablation, vs. nutrient demand from bacterial production and photosynthesis (see main text for calculations).

\begin{tabular}{|c|c|c|c|c|c|}
\hline & $\begin{array}{c}\text { Ablation flux } \\
\mu \text { moles } \mathbf{m}^{-2} \mathbf{h}^{-1}\end{array}$ & $\begin{array}{l}\text { Bacterial production demand } \\
\qquad \mu \text { moles } \mathrm{m}^{-2} \mathrm{~h}^{-1}\end{array}$ & $\begin{array}{l}\% \text { ablation flux of } \\
\text { bacterial production demand }\end{array}$ & $\begin{array}{l}\text { Photosynthesis demand } \\
\qquad \mu \text { moles } \mathrm{m}^{-2} \mathrm{~h}^{-1}\end{array}$ & $\begin{array}{c}\% \text { ablation flux of } \\
\text { photosynthesis demand }\end{array}$ \\
\hline DOC & 0.94 & $3.5 \pm 3.2$ & $70.0 \pm 85.7$ & $\mathrm{~N} / \mathrm{A}$ & N/A \\
\hline $\mathrm{TN}_{(\mathrm{aq})}$ & 0.17 & $0.54 \pm 0.48$ & $79.7 \pm 100$ & $2.8 \pm 2.2$ & $10.7 \pm 8.6$ \\
\hline $\mathrm{TP}_{(\mathrm{aq})}$ & 0.0038 & $0.05 \pm 0.04$ & $21.8 \pm 27.5$ & $0.23 \pm 0.19$ & $2.2 \pm 2.4$ \\
\hline
\end{tabular}

Error bars are $1 \sigma(n=16)$.
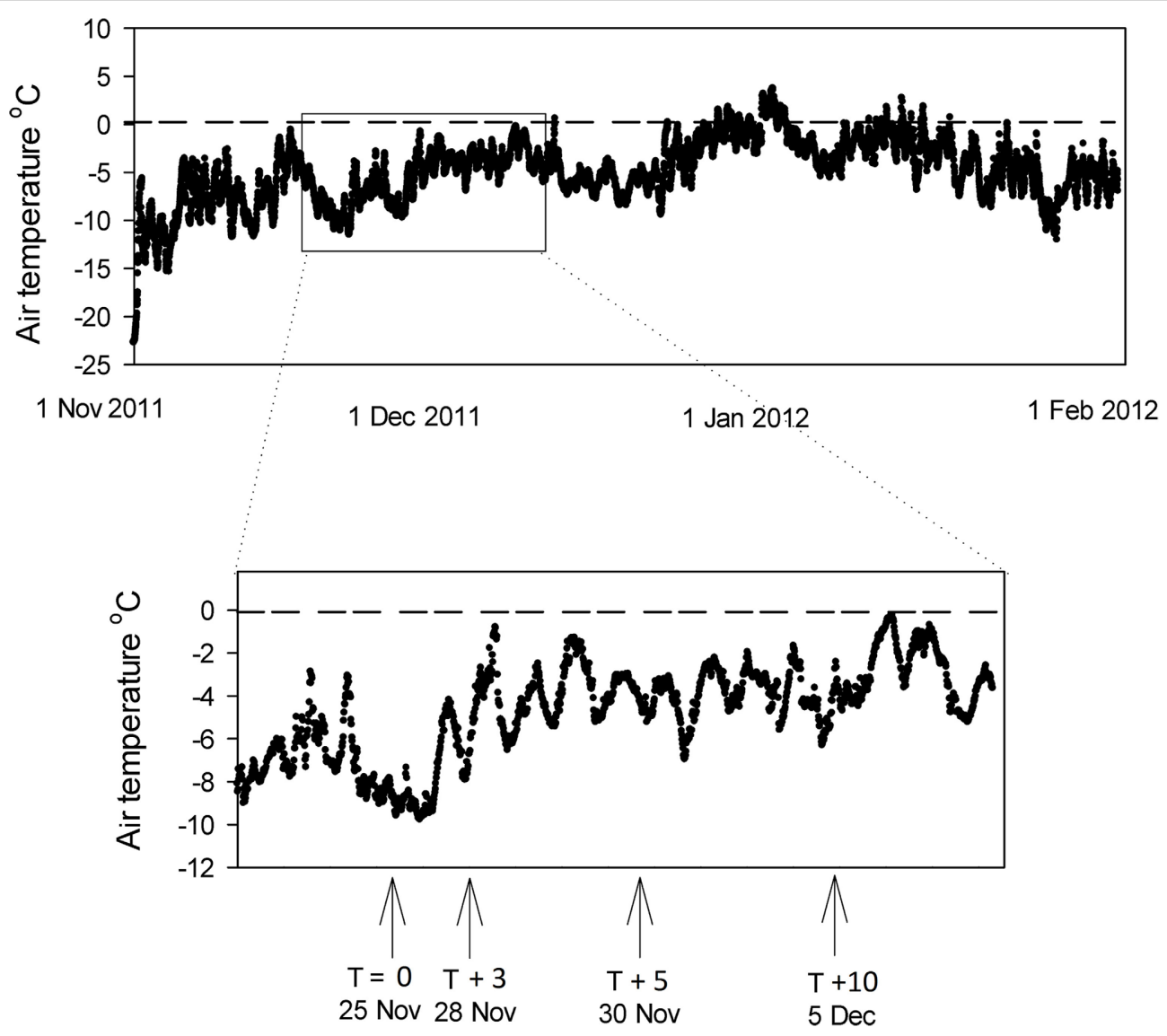

FIGURE 7 | Air temperature record for the surface of Canada Glacier during the 2011 season. Data from Fountain, www.mcmlter.org/queries/met/met_ stations.jsp\#CAAM. Inset shows ice core and cryoconite hole sampling points.

the DIC uptake kinetics of photosynthetic microbes within the cryoconite holes.

The likely reason for the relatively low DIC concentrations during the ionic pulse is the supersaturation of $\mathrm{CaCO}_{3}$ minerals (aragonite or calcite), driving DIC (and $\mathrm{Ca}^{2+}$ ) concentrations down (Tranter et al., 2004). This would be consistent with the relatively low mean enrichment factor for $\mathrm{Ca}^{2+}$ during $\mathrm{T}+3\left(2.9 \times\right.$ compared to $10.2 \times$ for $\mathrm{Mg}^{2+}$, and $9.3 \times$ for $\mathrm{Cl}^{-}$; Figure 1). This supersaturation could occur purely abiotically, via elevated $\mathrm{Ca}^{2+}$ and DIC concentrations in an early melt phase prior to measurements at $T+3$. In addition, elevated nutrient concentrations (DIC, nitrogen, phosphorus) may have promoted higher rates of photosynthesis in an early more nutrient enriched melt water, both consuming DIC and producing alkalinity to further drive carbonate equilibria toward carbonate precipitation (Tranter et al., 2004). This would be consistent with an elevated mean estimated autotrophic cell biomass during $T+3(14.4 \mu \mathrm{g}$ $\mathrm{C} \mathrm{g}^{-1}$, relative to $0.9-6.4 \mu \mathrm{g} \mathrm{C} \mathrm{g}^{-1}$ at other time points; Table 6), suggestive of a short-lived pulse of higher photosynthetic growth prior to $T+3$.

Ionic pulses in entombed cryoconite holes are likely important in shifting the timing and maxima of microbial activities to 
early, and potentially late, in the melt season. It follows that any net increase in nutrient uptake during the ionic pulse would have to be balanced by lower than initial concentrations of nutrients after the ionic pulse events, perhaps reducing rates of microbial activity. This hypothesis is consistent with some data from this study. Concentrations of $\mathrm{NH}_{4}^{+}$and $\mathrm{NO}_{2}^{-}$are reduced to below detection by the final time point (Table 2) perhaps contributing to the diminished rates of bacterial production (mean of $0.6 \times$ of initial levels; Table 7). Mineral precipitation reactions during ionic pulses could further reduce concentrations of nutrients such as DIC to levels that could limit subsequent microbial growth.

\section{POTENTIAL IMPACT OF IONIC PULSES ON MICROBIAL ACTIVITY IN OTHER CRYOSPHERE HABITATS}

The significant enrichment of nutrients and rates of bacterial production by ionic pulses in entombed cryoconite holes has relevance to the ecology of other habitats in the cryosphere where freeze-thaw occurs. Brines contained within veins in ice or permafrost at subzero temperatures are one potential habitat where ionic enrichment through freezing could support increased rates of microbial activity (Rohde and Price, 2007; Barletta et al., 2012). A recent study has suggested that the Antarctic ice sheet could contain $>500 \mathrm{~km}^{3}$ of brine filled ice veins, potentially supporting viable microbial life (Barletta et al., 2012). The ionic enrichment in veins may facilitate the maintenance and growth of microbial cells in the veins (Price, 2000). Rates of growth are however likely to be constrained by the physical dimensions of the veins, and the length of time that microbes can survive ultimately limited by the depletion of redox couples and nutrients.

A second habitat where freeze thaw events and ionic pulses may have a major impact on microbial activity is the subglacial environment. Under cold based and polythermal glaciers and ice sheets, regelation (pressure melting) of basal ice forms thin films of water, perhaps tens of microns thick (Raiswell et al., 2009), which will likely be enriched in nutrients relative to bulk ice in a similar manner to the cryoconite holes of this study. Nutrient enrichment during regelation is likely to enhance rates of microbial growth; a recent study demonstrated that rates of potential bacterial production (incubations at $2{ }^{\circ} \mathrm{C}$ ) in a MDV glacier (Taylor Glacier) were significantly enhanced by the addition of nutrients (Montross et al., 2013). While microbial growth in regelation films would remove some of these nutrients from solution, additional nutrients could potentially be provided from upstream by the lateral flow of non-regelated ice to the pressure point where pressure melting occurs.

\section{ACKNOWLEDGMENTS}

This work was funded by grants awarded to Andrew G. Fountain (NSF SF ANT1115245) and Alexandre M. Anesio (NERC NE/J02399X/1). We would like to thank the support staff at Lake Hoare field camp and Crary Laboratory (McMurdo) for all their logistical and analytical support, to Thermofisher Scientific and Paul Dewsbury for ion chromatography support, and to Dr. Liz Bagshaw for helpful comments on the draft manuscript.

\section{REFERENCES}

Anesio, A. M., Sattler, B., Foreman, C., Telling, J., Hodson, A., Tranter, M., et al. (2010). Carbon fluxes through bacterial communities on glacier surfaces. Ann. Glaciol. 51, 32-40. doi: 10.3189/172756411795932092

Bagshaw, E. A., Tranter, M., Fountain, A. G., Welch, K. A., Basagic, H., and Lyons, W. B. (2007). Biogeochemical evolution of cryoconite holes on Canada Glacier, Taylor Valley, Antarctica. J. Geophys. Res. Biogeosci. 112:G04535. doi: 10.1029/2007JG000442

Bagshaw, E. A., Tranter, M., Fountain, A. G., Welch, K., Basagic, H. J., and Lyons, W. B. (2013). Do cryoconite holes have the potential to be significant Sources of C, N, and P to downstream depauperate ecosystems of Taylor Valley, Antarctica? Arctic Antarct. Alp. Res. 45, 440-454. doi: 10.1657/1938-4246-45.4.440

Bagshaw, E. A., Tranter, M., Wadham, J. L., Fountain, A. G., and Mowlem, M. (2011). High-resolution monitoring reveals dissolved oxygen dynamics in an Antarctic cryoconite hole. Hydrol. Process. 25, 2868-2877. doi: 10.1002/hyp.8049

Barletta, R. E., Priscu, J. C., Mader, H. M., Jones, W. L., and Roe, C. H. (2012). Chemical analysis of ice vein microenvironments: II. Analysis of glacial samples from Greenland and Antarctica. J. Glaciol. 58, 1109-1118. doi: 10.3189/2012JoG12J112

Barrett, J. E., Virginia, R. A., Lyons, W. B., Mcknight, D. M., Priscu, J. C., Doran, P. T., et al. (2007). Biogeochemical stoichiometry of Antarctic Dry Valley ecosystems. J. Geophys. Res. Biogeosci. 112:G01010. doi: 10.1029/2005JG000141

Bellas, C. M., Anesio, A. M., Telling, J., Stibal, M., Tranter, M., and Davis, S. (2013). Viral impacts on bacterial communities in Arctic cryoconite. Environ. Res. Lett. 8:045021. doi: 10.1088/1748-9326/8/4/045021

Breitbarth, E., Mills, M. M., Friedrichs, G., and Laroche, J. (2004). The Bunsen gas solubility coefficient of ethylene as a function of temperature and salinity and its importance for nitrogen fixation assays. Limnol. Oceanogr. Methods 2, 282-288. doi: 10.4319/lom.2004.2.282

Christner, B. C., Kvitko, B. H., and Reeve, J. N. (2003). Molecular identification of Bacteria and Eukarya inhabiting an Antarctic cryoconite hole. Extremophiles 7, 177-183. doi: 10.1007/s00792-002-0309-0

Cook, J., Hodson, A., Telling, J., Anesio, A., Irvine-Fynn, T., and Bellas, C. (2010) The mass-area relationship within cryoconite holes and its implications for primary production. Ann. Glaciol. 51, 106-110. doi: 10.3189/172756411795932038

Cragin, J. H., Hewitt, A. D., and Colbeck, S. C. (1996). Grain-scale mechanisms influencing the elution of ions from snow. Atmos. Environ. 30, 119-127. doi: 10.1016/1352-2310(95)00232-N

Davies, T. D., Vincent, C. E., and Brimblecombe, P. (1982). Preferential elution of strong acids from a Norwegian Ice Cap. Nature 300, 161-163. doi: $10.1038 / 300161 \mathrm{a} 0$

Foreman, C. M., Sattler, B., Mikucki, J. A., Porazinska, D. L., and Priscu, J. C. (2007). Metabolic activity and diversity of cryoconites in the Taylor Valley, Antarctica. J. Geophys. Res. Biogeosci. 112:G04532. doi: 10.1029/2006JG0 00358

Fountain, A. G., Lyons, W. B., Burkins, M. B., Dana, G. L., Doran, P. T., Lewis, K. J., et al. (1999). Physical controls on the Taylor Valley ecosystem, Antarctica. Bioscience 49, 961-971. doi: 10.2307/1313730

Fountain, A. G., Nylen, T. H., Tranter, M., and Bagshaw, E. (2008). Temporal variations in physical and chemical features of cryoconite holes on Canada Glacier, McMurdo Dry Valleys, Antarctica. J. Geophys. Res. Biogeosci. 113:G01592. doi: 10.1029/2007JG000430

Fountain, A. G., Tranter, M., Nylen, T. H., Lewis, K. J., and Mueller, D. R. (2004). Evolution of cryoconite holes and their contribution to meltwater runoff from glaciers in the McMurdo Dry Valleys, Antarctica. J. Glaciol. 50, 35-45. doi: $10.3189 / 172756504781830312$

Gutschick, V. P. (1978). Energy and nitrogen fixation. BioScience 28, 571-575. doi: $10.2307 / 1307512$

Hein, M. (1997). Inorganic carbon limitation of photosynthesis in lake phytoplankton. Freshw. Biol. 37, 545-552. doi: 10.1046/j.1365-2427.1997.00180.x

Hodson, A., Paterson, H., Westwood, K., Cameron, K., and Laybourn-Parry, J. (2013). A blue-ice ecosystem on the margin's of the East Antarctic ice sheet. J. Glaciol. 59, 255-268. doi: 10.3189/2013JoG12J052

Hoefs, J. (1980). Stable Isotope Geochemistry, 2nd Edn. New York, NY: SpringerVerlag.

Hoffman, M. J., Fountain, A. G., and Liston, G. E. (2008). Surface energy balance and melt thresholds over 11 years at Taylor Glacier, East Antarctica. J. Geophys. Res. 113, F04014. doi: 10.1029/2008JF001029 
Maberly, S. C., and Spence, D. H. N. (1983). Photosynthetic inorganic carbon use by freshwater plants. J. Ecol. 71, 705-724. doi: 10.2307/2259587

Mcintyre, N. F. (1984). Cryoconite hole thermodynamics. Can. J. Earth Sci. 21, 152-156. doi: 10.1139/e84-016

Montross, S., Skidmore, M., Christner, B., Samyn, D., Tison, J.-L., Lorrain, R., et al. (2013). Debris-Rich Basal ice as a microbial habitat, Taylor Glacier, Antarctica. Geomicrobiol. J. 31, 76-81. doi: 10.1080/01490451.2013.811316

Mueller, D. R., Vincent, W. F., Pollard, W. H., and Fritsen, C. H. (2001). “Glacial cryoconite ecosystems: A bipolar comparison of algal communities and habitats. Nova Hedwigia Beiheft. Nova Hedwigia Beiheft. Algae and extreme environments. Ecology and Physiology," in Proceedings of the International Conference 11-16 September (Trebon), 173-197.

Porazinska, D. L., Fountain, A. G., Nylen, T. H., Tranter, M., Virginia, R. A., and Wall, D. H. (2004). The Biodiversity and biogeochemistry of cryoconite holes from McMurdo Dry Valley glaciers, Antarctica. Arctic Antarct. Alp. Res. 36, 84-91. doi: 10.1657/1523-0430(2004)036[0084:TBABOC]2.0.CO;2

Price, P. B. (2000). A habitat for psychrophiles in deep Antarctic ice. Proc. Natl. Acad. Sci. U.S.A. 97, 1247-1251. doi: 10.1073/pnas.97.3.1247

Raiswell, R., Benning, L. G., Davidson, L., Tranter, M., and Tulaczyk, S. (2009). Schwertmannite in wet, acid, and oxic microenvironments beneath polar and polythermal glaciers. Geology 37, 431-434. doi: 10.1130/G25350A.1

Redfield, A. C., Ketchum, B. H., and Richards, F. A. (1963). "The influence of organisms on the composition of seawater," in The Sea, ed M.H. Hill. (New York, NY: John Wiley), 26-77.

Rohde, R. A., and Price, P. B. (2007). Diffusion-controlled metabolism for longterm survival of single isolated microorganisms trapped within ice crystals. Proc. Natl. Acad. Sci. U.S.A. 104, 16592-16597. doi: 10.1073/pnas.0708183104

Sabacka, M., Priscu, J. C., Basagic, H. J., Fountain, A. G., Wall, D. H., Virginia, R. A., et al. (2012). Aeolian flux of biotic and abiotic material in Taylor Valley, Antarctica. Geomorphology 155, 102-111. doi: 10.1016/j.geomorph.2011.12.009

Stewart, W. D. P., Fitzgerald, G. P., and Burris, R. H. (1967). In situ studies on N2 fixation using acetylene reduction technique. Proc. Natl. Acad. Sci. U.S.A. 58, 2071-2078. doi: 10.1073/pnas.58.5.2071

Stibal, M., Anesio, A. M., Blues, C. J. D., and Tranter, M. (2009). Phosphatase activity and organic phosphorus turnover on a high Arctic glacier. Biogeosciences 6, 913-922. doi: 10.5194/bg-6-913-2009

Stibal, M., Telling, J., Cook, J., Mak, K. M., Hodson, A., and Anesio, A. M. (2012). Environmental controls on microbial abundance and activity on the greenland ice sheet: a multivariate analysis approach. Microbial Ecol. 63, 74-84. doi: 10.1007/s00248-011-9935-3

Stibal, M., Tranter, M., Telling, J., and Benning, L. G. (2008). Speciation, phase association and potential bioavailability of phosphorus on a Svalbard glacier. Biogeochemistry 90, 1-13. doi: 10.1007/s10533-008-9226-3
Telling, J., Anesio, A. M., Hawkings, J., Tranter, M., Wadham, J. L., Hodson, A. J., et al. (2010). Measuring rates of gross photosynthesis and net community production in cryoconite holes: a comparison of field methods. Ann. Glaciol. 51, 153-162. doi: 10.3189/1727564117959 32056

Telling, J., Anesio, A. M., Tranter, M., Irvine-Fynn, T., Hodson, A., Butler, C., et al. (2011). Nitrogen fixation on Arctic glaciers, Svalbard. J. Geophys. Res. Biogeosci. 116:G03039. doi: 10.1029/2010JG001632

Telling, J., Anesio, A. M., Tranter, M., Stibal, M., Hawkings, J., Irvine-Fynn, T., et al. (2012a). Controls on the autochthonous production and respiration of organic matter in cryoconite holes on high Arctic glaciers. J. Geophys. Res. Biogeosci. 117:G01017. doi: 10.1029/2011JG001828

Telling, J., Stibal, M., Anesio, A. M., Tranter, M., Nias, I., Cook, J., et al. (2012b). Microbial nitrogen cycling on the Greenland ice sheet. Biogeosciences 9, 2431-2442. doi: 10.5194/bg-9-2431-2012

Tranter, M., Fountain, A. G., Fritsen, C. H., Lyons, W. B., Priscu, J. C., Statham, P. J., et al. (2004). Extreme hydrochemical conditions in natural microcosms entombed within Antarctic ice. Hydrol. Process. 18, 379-387. doi: 10.1002/hyp.5217

Wharton, R. A., Vinyard, W. C., Parker, B. C., Simmons, G. M., and Seaburg, K. G. (1981). Algae in cryoconite holes on Canada Glacier in Southern Victorialand, Antarctica. Phycologia 20, 208-211. doi: 10.2216/10031-8884-20-2-208.1

Conflict of Interest Statement: The authors declare that the research was conducted in the absence of any commercial or financial relationships that could be construed as a potential conflict of interest.

Received: 03 September 2014; accepted: 24 November 2014; published online: 11 December 2014.

Citation: Telling J, Anesio AM, Tranter M, Fountain AG, Nylen T, Hawkings J, Singh VB, Kaur P, Musilova M and Wadham JL (2014) Spring thaw ionic pulses boost nutrient availability and microbial growth in entombed Antarctic Dry Valley cryoconite holes. Front. Microbiol. 5:694. doi: 10.3389/fmicb.2014.00694

This article was submitted to Terrestrial Microbiology, a section of the journal Frontiers in Microbiology.

Copyright () 2014 Telling, Anesio, Tranter, Fountain, Nylen, Hawkings, Singh, Kaur, Musilova and Wadham. This is an open-access article distributed under the terms of the Creative Commons Attribution License (CCBY). The use, distribution or reproduction in other forums is permitted, provided the original author(s) or licensor are credited and that the original publication in this journal is cited, in accordance with accepted academic practice. No use, distribution or reproduction is permitted which does not comply with these terms. 